Библиография произведений Н.В. Гоголя и литературы о нем на русском языке. 1929-1939

V.A. Voropaev (Moscow, Russia)

\title{
The Bibliography of N.V. Gogol's Works and Literature about Him in Russian. 1929-1939
}

1929

\section{ПРОИЗ ВЕДЕНИЯ}

Заколдованное место. Майская ночь. 2-е изд. М.; Л.: Гос. изд-во, 1929. 58 с. - (Дешевая библиотека классиков). 50000 экз.

Коляска / Гравюры на дереве Н. Бриммера. М.; Л.: Гос. изд-во, 1929. 28 с.: ил. 20000 экз.

Мертвые души: поэма / Послесл. Б. Г-ова. 2-е изд. М.; Л.: Гос. изд-во, 1929. 315, [1] с. (Дешевая библиотека классиков). 50000 экз.

Повесть о том, как поссорился Иван Иванович с Иваном Никифоровичем / Гравюры на дереве В. Конашевича. М.; Л.: Гос. изд-во, 1929. 94, [2] с. 20000 экз.

Повесть о том, как поссорился Иван Иванович с Иваном Никифоровичем / Предисл. и примеч. Д. Киреева. 2-е изд. М.; Л.: Гос. изд-во, 1929. 72 с. - (Дешевая библиотека классиков). 30000 экз.

Ревизор / Примеч., ред. и сопроводит. статья В.С. Нечаевой. М.; Л.: Гос. изд-во, 1929. 153 с. - (Дешевая библиотека классиков. Школьная серия). 60000 экз.

Ревизор / Примеч., ред. и сопроводит. статья В.С. Нечаевой. 2-е изд. М.; Л.: Гос. изд-во, 1929. 153 с. [6] - (Дешевая библиотека классиков. Школьная серия). 70000 экз.

Сорочинская ярмарка / Гравюры на дереве П. Бриммера. М.; Л.: Гос. изд-во, 1929. 52 с.: ил. 20000 экз.

Сочинения: [В 3 т.] / Ред. К. Халабаева и Б. Эйхенбаума; вступ. статья Л. Войтоловского. 3-е изд. М.; Л.: Гос. изд-во [ГИЗ], 1929. 15000 эКз.

T. I. Вечера на хуторе близ Диканьки. Миргород. XXI, 422, [2] с. Загл. вступ. статьи: Н.В. Гоголь (1809-1852).

Т. 2: Повести. Комедии. 489, [3] с. 
Т. 3: Мертвые души: поэма. Т. 1-2. 398, [2] с.

Сочинения / Ил. Д. М<итрохина >. 3-е изд. М.; Л.: Гос. изд-во, 1929. XVI, 623 с.: 16 л. ил. 15000 экз.

[Текст и примеч. соответствуют изданиям сочинений Гоголя в 3 т. / Под ред. К. Халабаева и Б. Эйхенбаума. М.; Л.: Гос. изд-во, 1927-1928.]

Тарас Бульба: повесть / Послесл. и примеч. И. Сергиевского. 2-е изд. М.; Л.: Гос. изд-во, 1929. 150, [2] с. - (Дешевая библиотека классиков). 50000 экз.

\section{Л И Т Е РАТ У РА}

Андреевич В. Гоголианец // Вечерний Киев. 1929. 26 апреля. № 96.

[К 100-летию со дня рождения Г.П. Данилевского.]

Аронсон М. и Рейсер С. Литературные кружки и салоны / Ред. и предисл. Б.М. Эйхенбаума. Л.: Прибой, 1929. 310, [1] с.: ил.

[Гоголь в салонах А.О. Смирновой, Е.М. Хитрово, графа В.А. Соллогуба, графини Е.П. Ростопчиной, А.П. Елагиной; на вечерах В.А. Жуковского, С.Т. Аксакова и пр.]

[Указ. имен.]

Атташева. ФЭКС [Фабрика эксцентрического актера] (1921-1929) // Советский экран. М., 1929. № 12. С. 6-7.

$<$ Белинский В.Г.> Виссарион Григорьевич Белинский в воспоминаниях современников / Сост. и коммент. М.К. Клеман; предисл. и ред. Н.К. Пиксанова. Л.: Academia, 1929. 432 с. - (Памятники литературного быта).

[Указ. имен.]

Берковский Н. Мейерхольд и смысловой спектакль // На литературном посту. М., 1929. № 2. C. 39-45.

[О постановке «Ревизора» Гоголя.]

B.E. Гоголь Николай Васильевич (1809-1852) // Малая Советская энциклопедия. Т. 2: Ванини - Дротик. М.: Акционерное общество Советская энциклопедия, 1929. Стлб. 537-540.

Валь В. «Вий» // Диктатура труда. Сталино, 1929. 16 марта. № 61(2054).

Вальбе Б. Памяти Гоголя (К 120-летию со дня его рождения) // Красная газета (вечерн. вып.). Л., 1929. 30 марта. № 80(2108). С. 2.

Виноградов В. Эволюция русского натурализма. Гоголь и Достоевский / Гос. институт истории искусств. Л.: Academia, 1929. 392 с.

Натуралистический гротеск. (Сюжет и композиция повести Гоголя «Нос»).

О литературной циклизации (По поводу «Невского проспекта» Гоголя и «Исповеди Опиофага» Де Квинси).

Из биографии одного «неистового» произведения («Последний день приговоренного к смерти»). Романтический натурализм (Жюль Жанэн и Гоголь).

К морфологии натурального стиля (Опыт лингвистического анализа петербургской поэмы «Двойник»).

Школа сентиментального натурализма (Роман Достоевского «Бедные люди» на фоне литературной эволюции 40-х годов).

[Рец.: Цейтлин А. // Русский язык в советской школе. М., 1929. Кн. 4; Берковекий Н. // Звезда. Л., 1929. № 4. С. 183-184; Бем А.Л. // Slavia. Прага, 1930. Т. ІХ. Вып. 1. С. 190-196.]

Волькенштейн В. Драматургия: метод исследования драматических произведений. 2-е изд., доп. М.: Федерация, 1929. 272 с.

[Ряд примеров из Гоголя; схема сюжета «Ревизора».] 
Газданов Г. Заметки об Эдгаре По, Гоголе и Мопассане // Воля России. Прага, 1929. № 5/6. С. 96-107.

[Перепечатано: Литературное обозрение. М., 1994. № 9-10. С. 78-83; Газданов Г. Собрание сочинений: В 5 т. Т. 1. М.: Эллис лак, 2009. С. 705-718.

Гиппиус 3. Гоголь и Белинский // Возрождение. Париж, 1929. 18 апреля. № 1416.

Гоголь в наши дни: К 120-летию со дня рождения // Наша газета: орган Ц.К. и Мосгуботдела профсоюза совторгслужащих. М., 1929. 31 марта. № 74(978).

Содерж.: Старосельский. «Пропавшие чиновники» (повесть по Гоголю); Ставроикий А. «Пиши, Гоголь»: стихотворный очерк; Снабженец. «Нужен ревизор»; Н.И. Тяжба.]

$<$ Гоголь Н.В.> [Н.В. Гоголь] // Смена. Л., 1929. 31 марта. № 74(1842). С. 5.

$<$ Гоголь Н.В.> Н.В. Гоголь // Резец: литературно-художественный журнал. Л., 1929. № $14(250)$. C. 9.

$<$ Гоголь Н.В.> Н.В. Гоголь в «Театре Петрушки» // Красная газета. Л., 1929. 15 декабря. № 286. C. 6 .

[О постановке «Повести о том, как поссорился Иван Иванович с Иваном Никифоровичем» в переделке Г. Тарасова.]

Гроссман Л. Н.В. Гоголь: К 120-летию со дня его рождения // Красная панорама. М., 1929. № 16. C. 8-9.

Гроссман-Рощиин И. Письма об искусстве (Как сделана «Шинель» Гоголя) // Октябрь. М., 1929. № 4. С. 184-196.

[Перепечатано: Гроссман-Рощин И. Искусство изменять мир. М.: Изд-во Федерация, 1930. C. $106-130$.]

Житомирский Д. «Нос»: опера Д. Шостаковича // Пролетарский музыкант. М., 1929. № 7-8. С. 33-39.

[Исполнение сюиты из оперы «Нос».]

Зеньковский В.В. Гоголь и Достоевский // О Достоевском: сб. статей / Под ред. А.Л. Бема. Т. 1. Прага: Петрополис, 1929. С. 65-76.

Зуммер В.M. Эсхатология Ал. Иванова // Ученые записки научно-исследовательской кафедры истории европейской культуры $<$ Харьковского ун-та $>$. Вып. 3 (посвящен акад. В.П. Бузескулу по случаю 70-летия со дня его рождения). Харьков, 1929. С. 387-409.

[Отд. оттиск: Харьков, 1929. 23 с.]

[Гоголь и А.А. Иванов.]

Иваск Ю. Слово о Гоголе // Новь: сб. произведений и статей молодежи ко Дню русской культуры. Ревель, 1929. № 2. С. 2.

Каверин В. Барон Брамбеус: история Осипа Сенковского, журналиста, редактора «Библиотеки для Чтения» Л.: Изд-во писателей в Ленинграде, 1929. 256 с.

[О.И. Сенковский и Гоголь: С. 251-252.]

[Перераб. и доп. изд.: М.: Наука, 1966. 237, [2] с.]

Киреев Д.И. Н.В. Гоголь: Жизнь, мировоззрение и литературная деятельность. М.; Л.: Гос. изд-во, 1929. 128, [1] с. - (Биографии русских и иностранных писателей).

[Библиография: Марксистская литература о Гоголе (12 названий).]

Крестова Л.В. Зрители первых представлений «Ревизора» // Научные труды Индустриального пед. ин-та им. К. Либкнехта. Социально-экономическая серия. Вып. 8. М., 1929. С. 5-23.

Кубиков И. Гоголь и Петербург // Русский язык в советской школе. М., 1929. № 2. С. 9-22. 
$<$ Кюхельбекер B.К.> Дневник В.К. Кюхельбекера: Материалы к истории русской литературной и общественной жизни 10-40 годов XIX века / Предисл. Ю.Н. Тынянова; ред., введение и примеч. В.Н. Орлова и С.И. Хмельницкого. Л.: Прибой, 1929. 377 с.

[C. 230: В.К. Кюхельбекер об «Арабесках»; С. 290: отзыв о первом томе «Мертвых душ». Текст исправлен по копии Института русской литературы (Пушкинский Дом).]

[Впервые: Русская Старина. 1875, 1883, 1884.]

Ларшин И. Урок сочинителю. Записка, найденная в бумагах покойного статского советника И.К. Шпекина. Рис. проф. Д. Кардовского // 30 дней. М., 1929. № 7. С. 18-27.

[Герой рассказа - персонаж «Ревизора», прочитавший комедию и повествующий о приезде настоящего ревизора.]

Лернер Н.О. Рассказы о Пушкине. Л.: Прибой, 1929. 222, [1] с.

Из содерж.:

«Великий меланхолик» (Пушкин и гоголевская «стихия»). С. 174-179.

Литовский О. «Мертвые души»: 120 лет со дня рождения Н.В. Гоголя // Беднота. М., 1929. 31 марта. № 3275. С. 3-4.

Луначарский А.В. Гоголь (К 120-летию со дня рождения) // Красная нива. М., 1929. 24 марта. № 13. С. 10-11.

[Со снимками памятника Н.В. Гоголю в Москве, работы скульптора Н.А. Андреева, и барельефов на памятнике с изображением гоголевских героев.]

Map B. Заметки о Гоголе (К 120-летию со дня рождения) // Заря Востока. Тифлис, 1929. 31 марта. № 72(2040). С. 5.

Могилы писателей расхищаются // Литературная газета. М., 1929. № 11. С. 3.

[О исчезновении плиты и разрушении решетки на могиле Гоголя.]

Назаренко Я.А. История русской литературы ХІХ века. 8-е доп. и испр. изд. М.; Л.: Гос. изд-во художественной литературы [ГИХЛ], 1929. 405, [1] с.

[О Гоголе: С. 79-97.]

[1-е, 2-е, 3-е изд. 1925; 4-е, 5-е, 6-е изд. 1927; 7-е изд. 1928; 9-е изд. 1931.]

Новгородиев П.И. Гоголь в его «Переписке с друзьями» // Россия и славянство. Париж, 1929. 27 апреля (№ 22).

[Статья-лекция, опубл. посмертно. Перепечатано: Трудный Путь. Зарубежная Россия и Гоголь / Сост., вступ. статья и коммент. М.Д. Филина. М.: Русскій Міръ, 2002. С. 40-53.]

«Нос» Шостаковича // Красная газета (вечерн. вып.). Л., 1929. 18 июня. № 150.

Панаева А. (А.Я. Головачева). Воспоминания. 1824-1870 / Исправл. издание под ред. и с примеч. К. Чуковского. Изд. 4-е. Л.: Academia, 1929. - (Памятники литературного быта). [О Гоголе: С. 95-97, 277-281 и др.]

[Впервые: Исторический Вестник. 1889 и отд. изд. Губинского (1890). В изд-ве Academia: 1927; 2-е изд. 1927; 3-е изд. 1929.]

Переверзев В. Гоголь Николай Васильевич (1809-1852) // Литературная энциклопедия: В 11 т. Т. 2 / Коммунистическая Академия. Секция литературы, искусства и языка; отв. ред. В.М. Фриче; отв. секретарь О.М. Бескин. М.: Изд-во Коммунистическая Академия, 1929. Стлб. 561-573.

Подготовка к зимнему сезону. Малый оперный театр // Красная газета (вечерн. вып.). Л., 1929. 12 августа. № 199.

[Беседа с режиссером театра Н.В. Смоличем о предполагаемой постановке «Носа» (по мотивам одноименной повести Гоголя).]

Ремизов А. Тайна Гоголя // Воля России. Прага, 1929. № 8/9. С. 63-67.

[Перепечатано: Трудный Путь. Зарубежная Россия и Гоголь / Сост., вступ. статья и коммент. М.Д. Филина. М.: Русскій Міръ, 2002. С. 54-59.] 
Сакулин П.Н. Русская литература: социолого-синтетический обзор литературных стилей. Ч. 2: Новая литература. М.: Государственная академия художественных наук, 1929. 642 с. - (ГАХН. Теория и история искусств. Вып. 12).

[О Гоголе С. 178, 392. 441, 552.]

Смирнова А.О. Записки, дневник, воспоминания, письма / Со статьями и примеч. Л.В. Крестовой; под ред. М.А. Цявловского. М.: Изд-во Федерация, 1929. 448 с.: ил. Предисл. С. 5-6.

А.О. Смирнова. Биографический очерк. С. 9-157.

Статьи о Гоголе. І. Записки о Гоголе. II. Воспоминания о Гоголе. С. 311-328.

Приложения:

К вопросу о достоверности так называемых «Записок» А.О. Смирновой. С. 355-393.

Примеч. С. 395-437.

Степанов Н. Повесть 30-х годов // Старинная повесть: [сб.]. Л.: Изд-во писателей в Ленинграде, 1929.

[О Гоголе: С. 19-22.]

Стовраикий А. Пиши, Гоголь: стихотворный очерк // Наша газета. Тула, 1929. 31 марта. № 74 .

Томин М. Н.В. Гоголь в советском искусстве (К 120-летию со дня рождения) // Харьковский Пролетарий. Харьков, 1929. 31 марта. № 74(1491). С. 3.

Тургенев И.С. Сочинения: В 12 т. / Под ред. К. Халабаева и Б. Эйхенбаума. Т. 3: Сцены и комедии / Подгот. текста и примеч. Ю.Г. Оксмана. [М.; Л.]: Гос. изд-во, 1929. 252 с. Примеч. С. 223-251.

[И.С. Тургенев-драматург и Гоголь: С. 232-233, 245-246, 248.]

Тынянов Ю.Н. Достоевский и Гоголь (к теории пародии) // Тынянов Ю.Н. Архаисты и новаторы. Л.: Прибой, 1929. С. 412-455.

[Первоначально: Тыняянов Ю. Достоевский и Гоголь: (К теории пародии). Пгр.: Опояз, 1921. 48 с. - (Сборники по теории поэтического языка). Перепечатано: Тынянов Ю. Архаисты и новаторы. Л.: Прибой, 1926. С. 412-455. См. также: Ardis Publishers, 1985 / Ardis reprint. Репринт издания: Л.: Прибой, 1929.]

Тынянов Ю. О ФЭКС’ах // Советский экран. М., 1929. № 14. С. 10.

Чаговеи Вс. Два Гоголя (120-я годовщина со дня рождения Гоголя.) // Вечерний Киев. Киев, 1929. 30 марта. № 73.

Шкловский В. Матвей Комаров, житель города Москвы. Л.: Прибой, 1929. 295 с.: ил. [Замечания об эволюции русской прозы от романов XVIII в. до Гоголя: С. 15, 81, 163, 164, 290.] [Рец.: Гуковский Г. Шкловский как историк литературы // Звезда. Л., 1930. № 1. С. 191-216. О Гоголе: С. 204-206.]

Шостакович Д. К премьере «Носа» // Рабочий и театр. Л., 1929. № 24.

Шостакович Д. Почему «Нос»? // Рабочий и театр. Л., 1929. № 3.

Шуберт А.И. Моя жизнь / Предисл., ред. и примеч. А. Дермана. Л.: Academia, 1929. (Театральные мемуары. Судьбы театра и театральный быт в освещении деятелей сцены. Серия книг под общей редакцией П.И. Новицкого и Евг. Кузнецова). VIII, 312 с.

[Встречи с Гоголем. Пьесы Гоголя на сцене: С. 74-75, 84, 148-149.

[Впервые: Ежегодник Императорских театров. СПб., 1911-1912.]

Эйхенбаум Б.М. Мой Временник: Словесность, наука, критика, смесь. Л.: Изд-во писателей в Ленинграде, 1929. 136, [8] с.

Из содерж.:

Гоголь и «дело литературы». С. 89-92. 


\section{ПРОИЗВЕДЕНИЯ}

Вечера на хуторе близ Диканьки. Сорочинская ярмарка. Пропавшая грамота. Заколдованное место. Майская ночь, или утопленница / Послесл. и примеч. Д. Киреева. М.; Л.: Гос. изд-во [Гиз], 1930. 128 с. - (Дешевая библиотека классиков). 35000 экз.

Вий. Ночь перед Рождеством. Страшная месть / Пояснит. статья и примеч. Ю. Перцовича. М.; Л.: Гос. изд-во, 1930. 222, [2] с. - (Дешевая библиотека классиков. Школьная серия). 50000 экз.

Женитьба: совершенно невероятное событие в двух действиях / Послесл. и примеч. И. Виноградова. М.; Л.: Гос. изд-во, 1930. 95 с. - (Дешевая библиотека классиков. Школьная серия). 35000 экз.

Мертвые души: [поэма] / Предисл. Г. Павловца. М.; Л.: Гос. изд-во, 1930. 383 с.: ил. (Дешевая библиотека Госиздата). 100000 экз.

[В тексте 15 иллюстраций А.А. Агина.]

Портрет. Невский проспект. Нос. Коляска / Ред., примеч. и пояснит. статья А.А. Богдановой. М.; Л.: Гос. изд-во, 1930. 235 с. - (Дешевая библиотека классиков. Школьная серия). 50000 экз.

Портрет. Невский проспект. Нос. Коляска / Ред., примеч. А.А. Богдановой; пояснит. статья А.В. Луначарского. 2-е изд., доп. М.; Л.: Гос. изд-во, 1930. 273 с. - (Дешевая библиотека классиков. Школьная серия). 100000 экз.

Загл. пояснит. статьи: Гоголь.

Ревизор: [комедия] / Ред., пояснит. статья и коммент. Н.Л. Бродского. 2-е изд., доп. М.; Л.: Гос. изд-во, 1930. 273 с. - (Русские и мировые классики / Под общ. ред. А.В. Луначарского и Н.К. Пиксанова). 10000 экз.

Загл. пояснит. статьи: Н.В. Гоголь и Ревизор.

Ревизор: [комедия] / Ред., и коммент. Н.Л. Бродского, пояснит. статья А.В. Луначарского. 2-е изд., доп. М.; Л.: Гос. изд-во, 1930. 273 с. - (Русские и мировые классики / Под общ. ред. А.В. Луначарского и Н.К. Пиксанова). 10000 экз.

Загл. пояснит. статьи: Гоголь.

Сочинения / Вступ. статья Л. Войтоловского; ил. Д. М[итрохина]. 4-е изд.. М.; Л.: Гос. изд-во, 1930. XVI, 623 с.: ил. 20000 экз.

Загл. вступ. статьи: Н.В. Гоголь.

Сочинения: [В 3 т.] / Ред. К. Халабаева и Б. Эйхенбаума; вступ. статья Л. Войтоловского. 4-е изд. М.; Л.: ГИЗ, 1930. 20000 экз.

Т. 1. Вечера на хуторе близ Диканьки. Миргород. XXI, 422, [2] с.

Загл. вступ. статьи: Н.В. Гоголь (1809-1852).

Т. 2. Повести. Комедии. 489, [3] с.

Т. 3. Мертвые души: поэма. Т. 1-2. 398, [2] с.

Старосветские помещики; Повесть о том, как поссорился Иван Иванович с Иваном Никифороничем / Послесл. В.С. Нечаевой. М.; Л.: Гос. изд-во, 1930. 124, [2] с. - (Дешевая библиотека классиков. Школьная серия). 100000 экз.

Шинель: [повесть] / Послесл. и примеч. В.С. Нечаевой. 2-е изд. М.; Л.: Гос. изд-во, 1930. 44, [2] с. - (Дешевая библиотека классиков). 50000 экз.

Шинель: [повесть] / Гравюры на дереве Д. Митрохина; предисл. И. Брюлловой-Шаскольской. М.; Л.: Гос. изд-во, 1930. 77 с.: ил. 25000 экз. 


\section{Л И Т Е РАТ У РА}

Анисимов Ив. Проблема Переверзева // Красная новь. М., 1930. № 2. С. 220-230.

[О концепции В.Ф. Переверзева в связи с его работами о творчестве Гоголя и Ф.М. Достоевского.]

Аристов-Литвак. «Черевички» в Госопере // Ленинградская правда. Л., 1930. 27 января. № 26. С. 4.

Белоусов И. Писательские гнезда: Дома в Москве и подмосковные усадьбы, где родились, жили или умерли известные русские писатели. М.: Московское товарищество писателей, 1930. 160, [2] с.

V. На Никитском бульваре - Н.В. Гоголь. С. 28-38.

Бем А.Л. [Рецензия] // Slavia. Прага, 1930. Т. IX. Вып. 1. С. 190-196.

[Рец. на кн.: Виноградов В. Эволюция русского натурализма. Гоголь и Достоевский. Л., 1929.]

Богданов-Березовский В. На репетициях «Носа» // Красная газета (вечерн. вып.). Л., 1930. 6 января. № 5. С. 4.

Боткин В.П. и Тургенев И.С. Неизданная переписка 1851-1869: По материалам Пушкинского Дома и Толстовского музея / Подгот. к печати Н.Л. Бродский. М.; Л.: Academia, 1930. - (Памятники литературного быта. Переписка В.П. Боткина и И.С. Тургенева).

[О Гоголе: С. 14, 18-21, 26-27, 32-33, 54-55, 166, 286-289: Письма В.П. Боткина к И.С. Тургеневу от 16 января, 21 февраля (о последних днях и смерти Гоголя), 5 марта 1852 г., без даты 1852 г. и 17 июня 1855 г. Письма И.С. Тургенева к В,П. Боткину от 17 июня 1855 г. и 10 марта 1862 г.]

Браудо Е. Премьера «Носа» Шостаковича в Ленинграде // Правда. М., 1930. 12 февраля. № 42(4487). С. 6.

Браудо Е. «Черевички» (Театр оперы и балета) // Красная газета (утрен. вып.). Л., 1930. 28 января. № 22. С. 4.

В борьбе за марксизм в литературной науке: сб. статей / Ред. В. Десницкого, Н. Яковлева, Л. Цырлина. Л.: Прибой, 1930. - (Вопросы методологии теории языка и литературы. Сборники и монографии / РАНИОН. Научно-исследовательский институт сравнительной истории литературы и языков Запада и Востока). 276, [2] с.

Из содерж:

Десниикий В. О пределах спецификации в литературной науке.

[Критика книги В.Ф. Переверзева о Гоголе: С. 7, 12-20, 30-32, 38-44. Перепечатано: Десниикий В.А. На литературные темы. Л.; М.: ГИХЛ, 1933.]

Яковлев Н.В. К теории литературного процесса (формалисты, Переверзев, Плеханов.

[Критические замечания о книге В.Ф. Перезерзева «Творчество Гоголя»: С. 62-67, 69-72.]

Волконский С., князь. «Нос» Гоголя по-французски // Последние новости. Париж, 1930. 6 марта. № 3270.

Вэдэ. «Вий» // Таганрогская правда. Таганрог, 1930. 29 августа.

Гвоздев А. «Нос» Шостаковича. Малый оперный театр // Красная газета (вечерн. вып.). Л., 1930. 20 января. № 17. С. 4.

$<$ Гоголь Н.В.> Н.В. Гоголь: сб. [2-е изд.] М.: Кооперативное изд-во писателей «Никитинские субботники», 1930. 254 с. - (Библиотека писателей для школы и юношества / Под ред. Е.Ф. Никитиной. III серия: Классики в марксистском освещении).

Содерж.:

Хронологическая таблица жизни и творчества Н.В. Гоголя. С. 5-10.

Переверзев В.Ф. Гоголь (Эволюция творчества, стиль и композиция). С. 11-99.

Луначарский А.В. Гоголь. С. 101-118.

Соловьев (Андреевич) Е. Н.В. Гоголь (1809-1852). С. 119-131. 
Войтоловский Л. Н.В. Гоголь. С. 133-172.

Коробка Н.И. Н.В. Гоголь. С. 173-226.

Зонин А. Трагедия Гоголя. С. 227-247.

Библиографический указатель. І. Произведения Н.В. Гоголя. ІІ. Биографические сведения. III. Библиография марксистской критики о творчестве Гоголя. С. 248-254.

[1-е изд.: М., 1928.]

$<$ Гоголь Н.В.> Н.В. Гоголь / Сост. В.В. Голубкова, Н.П. Горностаева, Б.Я. Лукьяновского, В. Сахарова. М.; Л.: Гос. изд-во [Гиз], 1930. 198 с. - (Литературно-критическая библиотека / Под ред. В.М. Фриче).

Содерж.:

От редакции.

От составителей.

Хронологическая канва жизни Гоголя.

Переверзев В. Стиль Гоголя.

Мандельштам И. Сравнения у Гоголя.

Брюсов В. Гипербола, как один из приемов творчества Гоголя.

Луначарский $A$. Что такое юмор.

Слонимский $A$. О характере юмора Гоголя.

Переверзев B. Социальная среда и творчество Гоголя.

Коробка Н. Повести из помещичьего быта.

Белинский В. О повестях Гоголя.

Кубиков И. Гоголь и царская бюрократия.

Данилов В. Социологический анализ «Ревизора».

Белинский В. Развитие действия в «Ревизоре».

Котляревский Н. «Мертвые души».

Рожков Н. Характеристика Чичикова.

Переверзев В. Характеры Гоголя.

Котляревский Н. Общественно-политические взгляды Гоголя.

Белинский В. Письмо к Гоголю.

Луначарский А.В. Гоголь.

Темы к произведениям Гоголя.

Библиографические указания.

Гоголь (Гоголь-Яновская) Марья Ивановна (1784-1868) // Большая Советская энциклопедия. Т. 17: Гимназия - Горовицы. М.: Акционерное общество Советская энциклопедия, 1930. Стлб. 350-351.

Гоголь (Гоголь-Яновский) Василий Афанасьевич // Большая Советская энциклопедия. Т. 17: Гимназия-Горовицы. М.: Акционерное общество Советская энциклопедия, 1930. Стлб. 349-350.

Горностаев Н.П. Тема денег в творчестве Гоголя (К социологии творчества Гоголя) // Русский язык в советской школе. М., 1930. № 4. С. 70-80.

Гроссман-Рощин И.С. Искусство изменять мир: [сб. статей по теории и истории литературы]. М.: Изд-во Федерация, 1930 [на обл.: 1929]. 352 с.

Из содерж.:

Письма об искусстве. Письмо третье. 1. Как сделана «Шинель» Гоголя. С. 106-130.

Фантастика «Мертвых душ» (К анализу мейерхольдовской постановки «Ревизора»). С. 305-320.

Денисов В.И. Социологический анализ двух редакций «Пропавшей грамоты» Гоголя // Литература и марксизм. М., 1930. № 2. С. 110-120.

Динамов С. Дискуссия о Переверзеве и задачи марксистского литературоведения // Красная новь. М., 1930. № 2. С. 211-219.

[По поводу книг В.Ф. Переверзева «Творчество Гоголя» и «Творчество Достоевского».] 
Дмитриева Н.И., Свищевская М.А. «Сорочинская ярмарка». Два сценария по Н.В. Гоголю. М.; Л.: Гос. изд-во, 1930. 60 с.: ил.

Ефремин А. Н.В. Гоголь: очерк // Красная нива. М., 1930. № 36. С. 18-19.

$K$-в M. «Ревизор» в театре глухонемых // Красная газета (вечерн. вып.). Л., 1930. 14 июня. № 139. С. 4.

Кубиков И.Н. Классики русской литературы: Пушкин, Гоголь, Тургенев, Достоевский, Некрасов, Л. Толстой, Салтыков-Щедрин, Гл. Успенский, Островский, Чехов и М. Горький: лекции, читанные в Воскресном университете 1 МГУ. М.: Изд-во 1-го Московского гос. ун-та, 1930. 295, [2] с.

Гоголь. С. 31-52.

Куликов В. «Нос» (Малый Оперный театр) // Ленинградский студент. Л., 1930. 20 января. № 4.

Л.Э. Русская реалистическая драма // Литературная энциклопедия: В 11 т. Т. 3 / Коммунистическая Академия. Секция литературы, искусства и языка; отв. ред. А.В. Луначарский; отв. секретарь О.М. Бескин. М.: Изд-во Коммунистическая Академия, 1930. Стлб. 510-518.

[В частности, о «Ревизоре» Гоголя.]

Лернер Н. Сент Бев о Гоголе // Звезда. М., 1930. № 1. С. 219-221.

Литературное бедствие // Литература и искусство. М., 1930. № 2. С. 50-70.

[И.С. Гроссман-Рощин и В.Ф. Переверзев о Гоголе.]

Луначарский А.В. Что вечно в Гоголе (Из статьи к 75-летию со дня смерти Гоголя, написанной в 1927 г.) // Красная нива. М., 1930. № 34. С. 18-19.

[С рисунком П. Боклевского к «Мертвым душам» и портретом Гоголя работы Ф. Моллера.]

Малков Н.П. «Майская ночь»: опера в 3 действиях и 4 картинах (По повести Н.В. Гоголя). Музыка Н.А. Римского-Корсакова. [Краткое либретто] [М.:] Теакинопечать, 1930. 16 с., с портр. и нотами. - (Путеводитель по оперным спектаклям).

Мериме П. Избранные произведения. М., Л.: Гослитиздат, 1930. 191 с. Николай Гоголь.

Монго А. Гоголь и Мериме // Revue de la littėature comparėe. 1930. № 10.

$<$ Мошков T.> Рабкоры о «Носе» // Красная газета (утрен. вып.). Л., 1930. 24 января. № 19. [Отзыв рабкора Т. Мошкова о постановке «Носа» Д. Шостаковича в Малом оперном театре в Ленинграде.]

Музалевский В. «Нос» - опера Д. Шостаковича (Малый оперный театр) // Красная газета (вечерн. вып.). Л., 1930. 20 января. № 17. С. 4.

Музалевский B. «Черевички» (Премьера в Театре оперы и балета) // Красная газета (вечерн. вып.). Л., 1930. 27 января. № 22. С. 4.

«Нос»: опера в 3 актах по Н.В. Гоголю. 15-е сочинение Д. Шостаковича (К постановке в Государственном Малом оперном театре.) Л., 1930. 13 с.: 1 л. бланк анкета. - (Государственный Малый оперный театр).

Переверзев В. Гоголь Николай Васильевич (1809-1852) // Большая Советская энциклопедия. Т. 17: Гимназия - Горовицы. М.: Акционерное общество Советская энциклопедия, 1930. Стлб. 351-368. 
Петров А. Николай I как репертуарный цензор (По архивным неопубликованным документам) // Советский театр. М., 1930. № 5-6. С. 44.

[О «Ревизоре» Гоголя.]

Пиотровский А. «Черевички» (Премьера в Театре оперы и балета) // Красная газета (вечерн. вып.). Л., 1930. 27 января. № 22. С. 4.

Против механистического литературоведения: дискуссия о концепции В.Ф. Переверзева / Коммунистическая Академия. Секция литературы, искусства и языка. М.: Издво Коммунистическая Академия, 1930. 201 с. - (Боевые вопросы коммунистической критики).

[Доклад С.Е. Щукина; содоклад В.Ф. Переверзева. Упоминания о книге В.Ф. Переверзева «Творчество Гоголя» в выступлениях И.А. Анисимова, И. Татарова, С. Динамова. Прения, заключительное слово В.Ф. Переверзева, С.Е. Щукина и И.М. Беспалова: С. 25, 26, 28, 52-55, $87-90,98,101,116,117,119,122,123,152,153,168$ и др.]

Русская литература: рабочая книга для подготовки в ВУЗ / В.П. Карякин, Н.Е. Кременский, В.А Мамонов, Г.Ю. Феддерс, В.П. Цветаев. 3-е испр. и доп. изд. М.: Работник просвещения, 1930. - (Готовься в ВУЗ: Пособие по подготовке в высшие учебные заведения / Под ред. А.П. Абиндера и К.И. Львова. Вып. 7). М.; Л.: Работник просвещения, 1930. 472 с.

[О Гоголе: С. 148-164. Биографический очерк, характеристика творчества; «Мертвые души»: Вопросы и задачи. Темы; «Ревизор»: Вопросы и задачи. Темы; «Шинель»: Вопросы и задачи. Темы. Библиография.]

Рыбичнская Е. Рабкоры о «Носе» // Красная газета (утрен. вып.). Л., 1930. 24 января. № 19. [Отзыв рабкора. Е. Рыбчинской о постановке «Носа» Д. Шостаковича в Малом оперном театре в Ленинграде.]

Саймон. «Нос» (премьера в Малом оперном театре) // Красная газета (утрен. вып.). Л., 1930. 24 января. № 19.

$<$ Сент-Бев Ш.>. Сент-Бев о Гоголе / Публ. и примеч. Н. Лернера // Звезда. М.; Л., 1930, № 1. C. 219-221.

[Письмо Ш. Сент-Бева к князю А.П. Голицыну (в переводе на русский язык).]

Тургенев и круг «Современника»: Неизданные материалы 1847-1861. М.; Л.: Academia, 1930. XLVII, 490 с.: ил.

[C. 151-153, 184, 306, 313 и др.: упоминания о Гоголе в письмах к И.С. Тургеневу - А.В. Дружинина и бр. Колбасиных. Письмо И.С. Тургенева к Е.М. Феоктистову от 26 февраля 1852 г. о смерти Гоголя (перепеч. из «Исторического Вестника» (1907. Кн. 2).]

Усиевич Е. Гоголь и его исследователь Переверзев // Литература и искусство. М., 1930. № 1. C. 54-67.

Фатов Н.Н. Классики русской литературы: общедоступные очерки для первоначального ознакомления. Вып. 1. М.; Алма-Ата: Казиздат, 1930. [8], 96 с.

Очерк 6: Н.В. Гоголь. С. 51-58.

Филиппов $B$. «Женитьба» Гоголя и режиссерский комментарий к ней. Текст комедии с разночтениями, литературно-сценический анализ, режиссерские замечания к отдельным местам комедии, словарь вызывающих сомнение в смысле произношенья слов, объяснение иностранных и устаревших слов и выражений. Ил. Ю. Ганф: Пособие для учащихся драмшкол, инструкторов и кружководов, для школьных спектаклей и самодеятельного театра. М., Теакинопечать, 1930. 188 с.: ил. - (На обл.: «Работа театра над текстом пьесы».)

Цейтлин А.Г. Русская литература XIX-XX вв. Задание пятое: Мелкопоместный стиль 30 -х годов. Творчество Гоголя. - (Бюро заочного обучения при педфаке 2-го МГУ. Отделение русского языка и литературы, школьное, лингвистическое и дефектологическое). На правах рукописи. [М., 1930].

[О Гоголе: С. 83-98.] 
«Черевички» (Перед премьерой) // Красная газета (вечерн. вып.). Л., 1930. 24 января. № 20. C. 4.

«Черевички»: комическая опера в 3 действиях / По Гоголю. Музыка П.И. Чайковского. Краткое либретто; вступ. статья Н. Малкова М., Теакинопечать, 1930. 16 с. - (Путеводитель по оперным спектаклям).

Загл. вступ. статьи: О постановке «Черевичек».

Чернылевский Н.Г. Избранные сочинения: В 5 т. Т. 4 / Под ред. А.В. Луначарского; подгот. к печати и примеч. Н.В. Богословского, В.В. Буша, Н.М. Чернышевской-Быстровой, П.А. Щелканова. М.; Л.: Гос. изд-во, 1930. ХXXI, 582 с.

[Очерки гоголевского периода русской литературы. Отрывок из статьи о сочинениях Гоголя.]

Чернылеевский Н.Г. Литературное наследие: В 3 т. Т. 3: Письма / Сост. Н.Л. Алексеева и Н.М. Чернышевской-Быстровой. М.; Л.: Гос. изд-во, 1930. 792 с.

[В письме к М.Н. Чернышевскому от 14 февраля 1885 г. из Астрахани Н.Г. Чернышевский высказывается о роли Гоголя в развитии русской литературы: С. 103-104.]

[Указ. имен.]

Шостакович Дм. «Нос»: опера в 3 действиях, 10 картинах (По Гоголю) / Музыка Д. Шостаковича [либретто]; вступ. статья Н. Малкова. М., Теакинопечать, 1930. 30 с. Загл. вступ. статьи: Творческий путь Н.А. Римского-Корсакова.

Щукин С. Две критики: Плеханов - Переверзев. М.: Гос. изд-во Московский рабочий, 1930. $253 \mathrm{c}$.

[Оценка книги В.Ф. Переверзева «Творчество Гоголя»: С. 30-35, 51-53, 68-75, 80, 103-106.]

Ян М. «Нос» // Смена. Л., 1930. 25 января. № 20. С. 6.

[«Нос» Д. Шостаковича.]

\section{1}

\section{ПРОИЗ В Е ДЕНИЯ}

Вечера на хуторе близ Диканьки. Сорочинская ярмарка. Пропавшая грамота. Заколдованное место. Майская ночь, или Утопленница / Послесл. и примеч. Д. Киреева. 2-е изд. М.; Л.: ОГИЗ, ГИХЛ, 1931. 101, [1] с. - (Дешевая библиотека классиков. Школьная серия). 100000 экз.

Вий. Ночь перед Рождеством. Страшная месть / Пояснит. статья и примеч. Ю. Перцовича. М.; Л.: ОГИЗ, ГИХЛ, 1931. 101, [1] с. - (Дешевая библиотека классиков. Школьная серия). 50000 экз.

Женитьба и Игроки / Вступ. статья М.А. Азбель. Л.; М.: ГИХЛ, 1931. 134, [2] с. - (Дешевая библиотека классиков. Школьная серия). 25000 экз.

Мертвые души: поэма / Послесл. Г. Павловца. М.; Л.: ОГИЗ - ГИХЛ, 1931. 416 с. - (Дешевая библиотека классиков. Школьная серия) 50000 экз.

Неизданные варианты к статье Гоголя «О движении журнальной литературы в 18341835 гг.» / Публ. В.В. Гиппиуса // Ученые Записки Пермского гос. ун-та. Отделение общественных наук. Вып. 2. Пермь, 1931. С. 125-126.

Первая страница гоголевской тетради № 312. Вселенная или история и описание всех народов, их религий, нравов, обычаев и пр. Египет / Публ. В.В. Гиппиуса // Ученые Записки Пермского гос. ун-та. Отделение общественных наук. Вып. 2. Пермь, 1931. С. 126. 
Повесть о том, как поссорился Иван Иванович с Иваном Никифоровичем / Послесл. Д. Киреева. 3-е изд. М.; Л.: ОГИЗ - ГИХЛ, 1931. 68 с. - (Дешевая библиотека классиков. Школьная серия). 100000 экз.

Ревизор: комедия в пяти действиях / Послесл. Д. Киреева. 3-е изд. М.; Л.: ОГИЗ ГИХЛ, 1931. 112 с. - (Дешевая библиотека классиков. Школьная серия). 100000 экз.

Собрание сочинений: В 3 т. / Под ред. Л.Б. Каменева и Л.И. Соловьева. М.; Л.: ГИХЛ, 1931. - (Приложение к журналу «Красная нива»). 65000 экз.

Т. 1. Вечера на хуторе близ Диканьки. Миргород / Биографический очерк Н.С. Ашукина; вступ. статья Н.К. Пиксанова; примеч. Н.С. Ашукина. 449 с.

Загл. вступ. статьи: Украинские повести Гоголя. С. 33-75.

[То же в кн.: Пиксанов Н.К. О классиках. М.: Московское товарищество писателей, 1933. С. 43-148.] Т. 2. Повести и комедии / Вступ. статьи А.В. Ефремина и А.Г. Цейтлина. Примеч. Н.С. Ашукина. $460 \mathrm{c}$.

Загл. вступ. статьи: Ефремин $A$. Социальный смысл петербургских повестей Гоголя

Загл. вступ. статьи: Цейтлин А.Г: Гоголь-драматург.

Т. 3. Мертвые души / Вступ. статьи В.А. Десницкого и Вл. Данилова. Примеч. Н.С. Ашукина. 375 с.: ил.

Загл. вступ. статьи: Десниикий B.A. «Мертвые души» Гоголя как поэма дворянского возрождения. Загл. вступ. статьи: Данилов Вл. «Мертвые души» Н.В. Гоголя.

[В тексте 14 иллюстраций А.А. Агина.]

Собрание сочинений: В 3 т / Под ред. В.И. Соловьева. М.; Л.: ГИХЛ, 1931. - (Приложение к журналу «Красная нива» на 1931 г.) 85000 экз.

Т. 1. Вечера на хуторе близ Диканьки. Миргород / Биографический очерк Н.С. Ашукина; вступ. статья Н.К. Пиксанова; примеч. Н.С. Ашукина. 449 с.

Загл. вступ. статьи: Украинские повести Гоголя.

Т. 2. Повести и комедии / Вступ. статьи А.В. Ефремина и А.Г. Цейтлина; примеч. Н.С. Ашукина. $460 \mathrm{c}$.

Загл. вступ. статьи: Ефремин А.В. Социальный смысл петербургских повестей Гоголя.

Загл. вступ. статьи: Цейтлин А.Г. Гоголь-драматург.

Т. 3. Мертвые души: [поэма] / Вступ. статьи В.А. Десницкого и В.В. Данилова; примеч. Н.С. Ашукина. 375 с.: ил.

Загл. вступ. статьи: Десницкий В.А. «Мертвые души» Гоголя как поэма дворянского возрождения. Загл. вступ. статьи: Данилов В.В. «Мертвые души» Н.В. Гоголя.

[В тексте 14 иллюстраций А.А. Агина.]

Шинель: [повесть] / Послесл. и примеч. В.С. Нечаевой. 3-е изд. М.; Л.: ГИХЛ, 1931. 46 с. - (Дешевая библиотека классиков. Школьная серия). 50000 экз.

\section{Л И Т Е РАТ У РА}

Аросев А. На боевых путях (Воспоминания) // Новый Мир. М., 1931. № 3. С. 80-95. [C. 47: отзыв А.М. Горького о Гоголе.]

Бродский-Краснов М., Друзин В. Краткий очерк истории русской литературы XIX и XX веков. Саратов: Гос. изд-во РСФСР, Нижневолжское краевое изд-во, 1931. 277, [3] с. [О Гоголе: С. 17-20.]

Вейдле В. Мериме, Гоголь, Пушкин // Возрождение. Париж, 1931. 20 августа.

Гиппиус B. Литературное общение Гоголя с Пушкиным // Ученые записки Пермского гос. ун-та. Отделение общественных наук. Вып. 2. Пермь, 1931. С. 61-126.

[Отд. оттиск: 1930 г.]

Гиппиус B. «Мертвые души» Гоголя в школе // Русский язык в советской школе. М., 1931. № 6-7. С. 68-79. 
$<$ Гоголь Н.В.> Н.В. Гоголь в письмах и воспоминаниях / Сост., предисл., коммент. В. Гиппиуса. М.: Федерация, 1931. 496 с.

Предисл. С. 3-6.

[Коммент. в тексте.]

Синхроническая канва жизни и творчества Н.В. Гоголя на фоне эпохи. С. 461-479.

[Указ. имен.]

[Рец.: Русский язык в советской школе. М., 1931. № 5. С. 200.]

[Переиздано: Гиппиус В. Гоголь. Воспоминания. Письма. Дневники... М.: Аграф, 1999. 464 с. (Сер. Литературная мастерская).]

Предисл. С. 5-8.

[Коммент. в тексте.]

Синхроническая канва жизни и творчества Н.В. Гоголя на фоне эпохи. С. 440-460.

Данилов В. Мелкопоместная идеология Гоголя в «Выбранных местах из переписки с друзьями» // Русский язык в советской школе. М. 1931. № 1. С. 73-85.

Демьянчик Ю.И. Николай Васильевич Гоголь как знамя единства русской культуры // Временник: научно-литературные записки Львовского Ставропигиона. Львов, 1931. С. 81-96.

Десниикий В. Жизнь и творчество Н.В. Гоголя (1809-1852) // Литературная учеба. Л., 1931. № 5. С. 20-42; № 6. С. 67-85.

[Перепечатано: Десниикий В. На литературные темы: [сб. статей.] Л.; М.: ГИХЛ, 1933. С. 173-218.]

Десницкий В. «Мертвые души» Гоголя, как поэма дворянского возрождения // Литературная учеба. Л., 1931. № 2. С. 50-66.

[1. Место «Мертвых душ» в творчестве Гоголя. 2. Сюжет «Мертвых душ» и социальная направленность 3. Идея социального мира в поместной среде. 4. Предшественники Гоголя в его концепции дворянского «возрождения». 5. Идейная основа «Мертвых душ». 6. «Мертвые души» и буржуазно-демократическая критика.]

Зайщев Б. Гоголь на Пречистенском // Возрождение. Париж, 1931. 29 марта. № 2126. С. 3-4.

[Перепечатано: Зайщев Б. Москва. Париж, 1939; 2-е изд. Мюнхен, 1960; 3-е изд. Мюнхен, 1973; Литературная учеба. М., 1988. № 3 / Публ. и вступ. статья Е.В. Воропаевой, примеч. В.А. Воропаева. С. 115-117; загл. вступ. статьи: Борис Зайцев о Гоголе. С. 111-115.]

Ильин В.Н. Достоевский и Гоголь // Вестник РСХД [Русское студенческое христианское движение]. Париж, 1931. № 3. С. 10-17.

[Перепечатано: Ильин В.Н. Эссе о русской культуре. СПб.: Акрополь, 1997. С. 60-71.]

Капнист-Скалон С.В. Воспоминания / Ред., вступ. статья и примеч. Ю.Г. Оксмана // Воспоминания и рассказы деятелей тайных обществ 1820-х годов. Т. I / Общ. ред. Ю.Г. Оксмана и С.Н. Чернова. М.: Изд-во Всесоюзного Общества политкаторжан и ссыльнопоселенцев, 1931. Приложения. С. 289-428.

[Первоначально: Исторический Вестник. 1891. Кн. 5-7.]

[О Гоголе и его родителях.]

Литературные дискуссии (Переверзевщина, буржуазный либерализм в литературе. «Перевал». Воронский. Творческие пути пролетарской литературы. Библиографический вып. № 1 / Коммунистическая Академия. Кабинет пролетарской литературы Института искусства и языка. М.: Изд-во Коммунистическая Академия, 1931. 23 с.

[О Гоголе: С. 5-10.]

Лобов Л.П. Из истории русского литературного языка (Гоголь, Толстой, Достоевский) // Ученые записки Пермского гос. ун-та. Отделение общественных наук. Вып. 2. Пермь, 1931. С. $127-152$.

[Язык Гоголя: С. 127-136.]

$<$ Лорер Н.И.> Записки декабриста Н.И. Лорера / Коммунистическая Академия; ред. М.Н. Покровского; подгот. к печати и коммент. М.В. Нечкиной. М.: Гос. социальго-экономическое изд-во, 1931. 448 с.: ил. 
[А.О. Россет-Смирнова и ее ходатайство перед Николаем I о пособии Гоголю: С. 268-269.]

Малков Н.П. «Майская ночь»: опера в 3 действиях и 4 картинах (По повести Н.В. Гоголя). Музыка Н.А. Римского-Корсакова. [Краткое либретто] / Вступ. статья Н. Малкова. 2-е изд. М.: ГИХЛ, 1931. 15 с. - (В помощь зрителю).]

Загл. вступ. статьи: Творческий путь Н.А. Римского-Корсакова.

«Мертвые души» Гоголя в Художественном театре // Советское искусство. М., 1931. 23 октября. № 55(126). С. 4.

Назаренко Я.А. История русской литературы XIX века. 9-е доп. и испр. изд. М.; Л.: Гос. изд-во художественной литературы [ГИХЛ], 1931. 405, [1] с.

[О Гоголе: С. 79-97.]

[1-е, 2-е, 3-е изд. 1925; 4-е, 5-е, 6-е изд. 1927; 7-е изд. 1928; 8-е изд. 1929.]

Оксман Ю.Г. Гоголь Николай Васильевич (1809-1852) // Пушкин А.С. Полное собрание сочинений: В 6 т. / Под общ. ред. Демьяна Бедного, А.В. Луначарского, П.Н. Сакулина, В.И. Соловьева, П.Е. Щеголева. Т. 6: Путеводитель по Пушкину. М.; Л.: ГИХЛ, 1931. (Приложение к журналу «Красная нива» на 1931 г.). С. 99-100.

Рыбакова Н. Как работал Гоголь // Литературная учеба. Л., 1931. № 7. С. 53-70.

Рыклин Г. «Ночь перед Рождеством» (Театр сатиры) // Известия. М., 1931. 8 октября. № 231. C. 6.

[«Ночь перед Рождеством» Гоголя в интерпретации В. Массэ и В. Тикота.]

Слонимский $A$. Черниговцы: повесть о восстании черниговского полка (1826). 3-е изд. М.: Гос. изд-во юношеской и детской литературы «Молодая гвардия», 1931. 256 с. (Дешевая библиотека Огиза. Серия школьника и пионера).

[О Гоголе: С. 106-108.]

Смирнова-Россет А.О. Автобиография (Неизданные материалы) / Подгот. к печати Л.В. Крестовой; предисл. Д.Д. Благого. М.: Изд-во «Мир», 1931. 364 с.

[Воспоминания о Гоголе даны в исправленном виде по сравнению с текстом 1929 г. С. 271-311, 331-334.]

Соллогуб В.А., граф. Воспоминания / Ред. и примеч. С.П. Шестерикова; вступ. статья П.К. Губера. М.; Л.: Academia, 1931. 653 с.

[О Гоголе: С. 271-273, 308, 311, 378-380, 409, 512-518.

[Впервые: Исторический Вестник. 1886; отд. изд. 1887.]

Татаров И. Письмо в редакцию // Историк-марксист. М., 1931. Т. 21. С. 140-142.

[По поводу речи И. Татарова на дискуссии в Коммунистической Академии о понимании русского исторического процесса в книге В.Ф. Переверзева «Творчество Гоголя».]

Флоровский Г.В. Религиозные темы Достоевского // Россия и славянство. Париж, 1931. 21 февраля.

[В частности, о Гоголе.]

Цявловский М.А. Книга воспоминаний о Пушкине. М.: Кооперативное изд-во «Мир», 1931. 383 с.

Из содерж.:

Иваниикиий Н.И. Письмо в редакцию. С. 328-332.

[Первоначально: Отечественные Записки. 1853. Февраль. Отд. VII. С. 119-121.]

[Воспоминания студента Санкт-Петербургского университета о профессорской деятельности Гоголя. Посещение А.С. Пушкиным и В.А. Жуковским лекции Гоголя.]

Чемоданов. «Женитьба»: новая радиоопера, текст Н.В. Гоголя. Музыка М.П. Мусоргского и М.М. Ипполитова-Иванова (Радиобеседа) // Говорит СССР. М., 1931. № 2. С. 10-13. 
Черевички: комическая опера в 3 действиях. Текст (по Гоголю) Я.П. Полонского, музыка П.И. Чайковского. [Краткое либретто.] Вступ. статья: Н. Малкова. 2-е изд. М.; Л.: Гос. изд-во художественной литературы, 1931. 16 с. - (В помощь зрителю).

Загл. вступ. статьи: О постановке «Черевичек».

Чернышевский Н.Г. Дневник / Под ред. Н.Л. Алексеева. Ч. I: 1848-1849. М.: Изд-во Всесоюзного Общества политкаторжан и ссыльнопоселенцев, 1931. XVI, 373 с.

[Указ. имен.]

Шувалов Н. «Сорочинская ярмарка» (Премьера в Малом оперном театре) // Красная газета (утрен. вып.). Л., 1931. 29 декабря. № 308. С. 4.

Янковский М. «Сорочивская ярмарка» (Премьера в Малом оперном театре) // Красная газета (вечерн. вып.). Л., 1931. 25 декабря. № 303. С. 3.

Яцевич A. Пушкинский Петербург / Обложка и рис. А. Обермиллера. Л.: Общество «Старый Петербург - Новый Ленинград», 1931. 209 с.: ил.; 20 л. ил.

[Улицы и дома, в которых жил Гоголь в Санкт-Петербурге: С. 76, 91-95, 100-103, 124-132, 192.]

Шевченко Т.Г. Дневник / Предисл. А. Старчакова, ред., вступ. статья и примеч. С.П. Шестерикова. М.; Л.: Academia, 1931, 437 с.

[Указ. имен.]

\section{2}

\section{ПРОИ З В ДЕНИЯ}

Неизданное письмо к Н.В. Путяте / Коммент. К. Пигарева // Звенья: сб. материалов и документов по истории литературы, искусству и общественной мысли XIX века / Под ред. В. Бонч-Бруевича, А.В. Луначарского. Т. 1. М.; Л.: Academia, 1932. С. 93-95.

[Письмо от 19 август 1849 г., Абрамцево.]

Повесть о том, как поссорился Иван Иванович с Иваном Никифоровичем / Послесл. Д. Киреева. 4-е изд. М.; Л.: ГИХЛ, 1932. 64 с. - (Дешевая библиотека классиков. Школьная серия). 75000 экз.

Ревизор: комедия в пяти действиях / Послесл. Д. Киреева. 4-е изд.. М.; Л.: ГИХЛ, 1932. 112 с. - (Дешевая библиотека классиков. Школьная серия). 75000 экз.

Старосветские помещики: [повесть] / Послесл. С. Шувалова. 3-е изд. М.; Л.: ГИХЛ, 1932. 38 с. - (Дешевая библиотека классиков. Школьная серия). 100000 экз.

\section{Л И Т Е РАТ У РА}

Амфитеатров A.[B.] Запоздалый юбилей // Сегодня. Рига, 1932. 26 июля.

[По поводу 100-летия выхода в свет «Вечеров на хуторе близ Диканьки» Гоголя.]

Амфитеатров А. Женщины Гоголя (К 80-й годовщине кончины Гоголя) // Сегодня. Рига, 1932. 6 марта.

[Перепечатано: Трудный Путь. Зарубежная Россия и Гоголь / Сост., вступ. статья и коммент. М.Д. Филина. М.: Русскій Міръ, 2002. С. 60-67.]

Бескин Э. «Мертвые души» в МХТ им. Горького // Рабочая Москва. М., 1932. 14 декабря. № 291.

[С рисунками: М.М. Тарханов в роли Собакевича и В.Я. Станицын в роли губернатора.]

Бицилли П. Зощенко и Гоголь // Числа. Париж, 1932. № 6.

[Переиздано: Лицо и маска Михаила Зощенко / Сост. Ю.В. Томашевского. М.: Олимп-ППП, 1994. С. 179-183; Бицилли П.М. Трагедия русской культуры. Исследования. Статьи. Рецензии. М.: Русский путь, 2000. С. 464-468.] 
Вересаев В.В. Как работал Гоголь. М.: Кооперативное изд-во «Мир», 1932. 80 с. - (Как работали классики / Ред. серии Д.Д. Благой. Вып. 1).

[Рец.: Гринвальд Я. Как работал Гоголь // Вечерняя Москва. М., 1932. 21 октября. № 244. С. 3; Сергиевский И. // Литературная газета. М., 1934. 12 апреля. № 145.]

Верховский Н. Комедия так и не была написана. «Владимир 3-й степени» в филиале Госдрамы // Красная газета (вечерн. вып.). Л., 1932. 7 октября. № 233. С. 3.

Глебов И. Симфонические этюды. Ленинградская гос. филармония. Л., 1932. 329 с.

[C. 51-68: «Майская ночь»; С. 85-102: «Ночь перед Рождеством; С. 173-176: «Черевички».]

Голенищев-Кутузов И. Гоголь в Италии // Возрождение. Париж, 1932. 2 апреля. № 2496. [Перепечатано: Голенищев-Кутузов И.Н. Лики времени: Парижские эссе. М.: Изд-во МЦНМО [Московский центр непрерывного математического образования], 2004. С. 192-195.

Гринвальд Я. «Мертвые души» в МХАТ СССР им. Горького // Вечерняя Москва. М., 1932. 11 декабря. № 286(2713). С. 3.

[С рисунками Лиса: И.М. Москвин в роли Ноздрева, В.О. Топорков в роли Чичикова, М.М. Тарханов в роли Собакевича.]

Д.Б. «Сорочинская ярмарка» в Музыкальном театре им. Вл. Немировича-Данченко // Красная газета (вечерн. вып.). Л., 1932. 10 января. № 108. С. 3.

Державин К.Н. Эпохи Александрийской сцены / Предисл. А.В. Луначарского. Л.: Ленгихл [Ленинградское отделение гос. изд-ва художественной литературы], 1932. 239, [4] с. [О «Ревизоре» Гоголя: С. 72-73.]

Добролюбов Н.А. Дневники 1851-1859 / Ред. и вступ. статья В. Полянского. 2-е изд. М.: Изд-во Всесоюзного Общества политкаторжан и ссыльнопоселенцев, 1932. 289, [2] с.: ил. [C. 108, 164: Н.А. Добролюбов о постановке «Ревизора» в Михайловском театре 2 января 1857 г.]

Ильин В.Н. Достоевский и Гоголь // Orient und Occident: Blätter für Theologie und Soziologie. Leipzig, 1932. Heft. 10.

Ильинский А. «Выбритый ус» (Драма Н.В. Гоголя) // Красная газета (вечерн. вып.). Л., 1932. 14 октября. № 239. С. 4.

Кири И. «Мертвые души»: К постановке в МХАТ СССР им. Горького // Комсомольская правда. М., 1932. 26 ноября. № 272(2353). С. 4.

Крути И. Поэма, пьеса, спектакль: «Мертвые души в МХТ им. Горького // Советское искусство. М., 1932. 21 декабря. № 58(196). С. 3.

Марвич C. «Катай-валяй, было бы горячо». О постановке в Госдраме в Ленинграде пьесы А. Прейса «Владимир III степени» // Красная газета (вечерн. вып.). Л., 1932. 20 октября. № 244 (3219). C. 3.

$<$ Мусоргский М.П.> М.П. Мусоргский: К пятидесятилетию со дня смерти. 1881-1931: Статьи и материалы / Под ред. Ю. Келдыша и В. Яковлева. М.: Гос. музыкальное изд-во, $1932.350 \mathrm{c}$.

[Указ. имен.]

Мусоргский М.П. Письма и документы / Гос. Публичная библиотека в Ленинграде; собрал и пригот. к печати А.Н. Римский-Корсаков при участии В.Д. Комаровой-Стасовой. М.; Л.: Гос. музыкальное изд-во, 1932. 573, [3] с.: ил.

[Указ. имен.]

На Большой сцене. К открытию сезона филиала Госдрамы // Красная газета (вечерн. вып.). Л., 1932. 25 октября. 
[Заслуженный деятель искусств режиссер Л.С. Вивьен о постановке «Владимира 3-й степени» Гоголя.]

Неизданные письма Л.Н. Толстого, И.А. Гончарова, Н.А. Некрасова, Ф.М. Достоевского, А.Ф. Писемского и других из архива А.Н. Островского: По материалам Гос. театрального музея А.А. Бахрушина / Пригот. к печати М.Д. Прыгунов, Ю.А. Бахрушин и Н.Л. Бродский. М.; Л.: Academia, 1932. - (Памятники литературы. Труды Гос. театрального музея им. Бахрушина. Т. I).

[С. 347: письмо А.Ф. Писемского от 20 марта 1852 г. (о смерти Гоголя); С. 565: письмо Н.С. Тихонравова [1885 г.] (о тексте «Ревизора»); упоминания о Гоголе на С. 70, 109, 354, 402, 437, 551, 590 в письмах И.А. Гончарова, А.Н. Плещеева, Я.П. Полонского, М.М. Стасюлевича и И.С. Тургенева.]

Новицкий П. «Мертвые души» // Известия. М., 1932. 22 декабря. № 352.

[В тексте шаржи Б. Ефимова: М.М. Тарханов в роли Собакевича, В.О. Топорков в роли Чичикова, И.М. Москвин в роли Ноздрева.]

Оружейников Н. Классическое наследство на сцене: «Мертвые души» в МХАТ им. Горького // Гудок. М., 1932. 20 декабря. № 292(3827). С. 4.

Пиксанов Н. Украинские повести Гоголя // Пиксанов Н. О классиках: сб. статей. М., 1932. C. 43-148.

Римский-Корсаков Н.А. Летопись моей музыкальной жизни. 4 испр. и доп. изд. с введением, примеч., приложениями, указателями и хронографом, составленными А.Н. Римским-Корсаковым. М.: ОГИЗ, Гос. музыкальное изд-во, 1932. IV, 363 с.: нот. и ил.

[О Гоголе: С. 256-266; С. 162-164: «Ночь перед Рождеством»; С. 171-172: «Майская ночь».]

Сахновский В.Г. Гоголь в МХАТ СССР им. Горького. Как и почему ставятся «Мертвые души»: Итоги двухлетней работы // Советское искусство. М., 1932. 15 ноября. № 52.

Феликс. «Мертвые души». Письмо из Москвы // Красная газета (вечерн. вып.). Л., 1932. 10 декабря. № 286(3261). С. 3.

Цимбал С. Под знаком Гоголя. «Владимир III степени» в филиале Госдрамы // Красная газета (утрен. вып.). Л., 1932. 4 октября. № 231(4393). С. 4.

Чернышевский Н.Г. Дневник / Под ред. Н.Л. Алексеева. Ч. II: 1850-1853. М.: Изд-во Всесоюзного Общества политкаторжан и ссыльнопоселенцев, 1932. 410 с.

[Указ. имен.]

1933

\section{ПРОИЗ В ЕДЕНИЯ}

Мертвые души: поэма. [М.:] ГИХЛ, 1933. 430 с. (Книгу - социалистической деревне. Дешевая библиотека ОГИЗ). 50000 экз.

Мертвые души: поэма. 2-е изд. М.; Л.: ГИХЛ, 1933. 430 с. - (Школьная библиотека классиков). 75000 экз.

Письмо к П.Я. Убри / Коммент. Н. Лернера // Звенья: сб. материалов и документов по истории литературы, искусству и общественной мысли XIX века / Под ред. В. Бонч-Бруевича, А.В. Луначарского. Т. 2. М.; Л.: Academia, 1933. С. 285-286.

[Письмо от 8 марта (н. ст.) 1847 г., Неаполь.]

Повесть о том, как поссорился Иван Иванович с Иваном Никифоровичем. 5-е изд. М.; Л.: ГИХЛ, 1933. 64 с. - (Школьная библиотека классиков). 50000 экз. 
Ревизор: комедия в пяти действиях / Послесл. Д. Киреева. 5-е изд. М.; Л.: ГИХЛ, 1933. 112 с. - (Дешевая библиотека классиков. Школьная серия). 75000 экз.

Старосветские помещики: [повесть] / Послесл. С. Шувалова. 4-е изд. М.; Л.: ГИХЛ, 1933. 38 с. - (Дешевая библиотека классиков. Школьная серия). 73000 экз.

\section{Л И Т Е РАТ У РА}

Батенков Г.С. Данные (повесть собственной жизни) // Воспоминания и рассказы деятелей тайных обществ 1820 годов: В 2 т. Т. 2. М.: Изд-во Всесоюзного Общества политкаторжан и ссыльнопоселенцев, 1933.

[C. 97: Сообщение Батенкова о переписке с Гоголем по поводу «Выбранных мест из переписки с друзьями» и «Мертвых душ».]

Бельй А. Непонятый Гоголь // Советское искусство. М., 1933. 20 января. № 4. С. 4.

[О постановке «Мертвых душ» МХАТом. Авторизованная запись доклада во Всеросскомдраме [Всероссийское общество композиторов и драматических писателей.]

[Перепечатано: Вопросы философии. М., 1990. № 11.]

Браудо E. Новая постановка «Майской ночи» в студии им. Станиславского в Москве // Красная панорама. Л., 1933. №7. С. 11 и 12.

Вересаев B. К биографии Гоголя (Заметки) // Звенья: сб. материалов и документов по истории литературы, искусству и общественной мысли XIX века / Под ред. В. Бонч-Бруевича, А.В. Луначарского. Т. 2. М.; Л.: Academia, 1933. С. 286-293.

[1. Предки Гоголя и его настоящая фамилия. 2. Сын девочки-подростка или взрослой женщины (О матери Гоголя.)]

Вересаев В. Гоголь в жизни: Систематический свод подлинных свидетельств современников / Ил. на отд. листах. М.; Л.: Academia, 1933. 526, [3] с.: 15 вклад. лист.

Вересаев В.В. Предисловие. С. 7-8.

Примеч. С. 512-524.

[Краткая характеристика упоминаемых лиц в алфавитном порядке.]

Алфавитный указатель цитируемых авторов и документов. С. 525-527.

Перечень иллюстраций на отдельных листах. С. 528.

[Рец.: Сергиевский И. Агония жанра // Литературный критик. М., 1933. № 1. С. 143-146; Литературный критик. М., 1933. № 3; КиПР. 1933. № 10; Полнер Т.В. // Современные записки. Париж, 1934. № 56. С. 430-432.]

Вертышев К.Н. Воспоминания и мысли // Театр русской драмы. Харьков, 1933. 17 ноября. № 2. С. 3.

[Об исполнителях роли Городничего в «Ревизоре» Гоголя.]

Вокруг постановки «Мертвых душ»: встреча рабочих с постановщиком и актерами МХТ // Рабочая Москва. М., 1933. 3 февраля. № 29. С. 4.

Данилов С.С. «Ревизор» на сцене / Предисл. Н.В. Петрова. Харьков: Изд. Харьковского гос. театра русской драмы, 1933. 144 с.: ил. - (Библиотека Харьковского гос. театра русской драмы. Вып. 2: К премьере спектакля «Ревизор» в ноябре 1933 г.).

[Работа Гоголя над «Ревизором». Сценическая история пьесы. В примеч. дана библиография литературы о постановках «Ревизора» (С. 133-143).]

[Рец.: Верховский Н. // Красная газета (вечерн. вып.). Л., 1934. 31 марта. № 74; Пиксанов Н. // Литературный Ленинград. Л., 1935. 31 марта. № 15.]

Державин К. Б.А. Горин-Горяинов // Рабочий и театр. Л., 1933. № 13. С. 9-10.

[Хлестаков в исполнении Б.А. Горин-Горяинова.]

Десниикий В.А. На литературные темы: [сб. статей]. <Кн. 1.> Л.; М.: ГИХЛ, 1933. 390, [2] с. О пределах спецификации в литературной науке (Критика книги Переверзева о Гоголе).

Жизнь и творчество Н.В. Гоголя. 1809-1852. 
[Впервые: Литературная учеба. Л., 1931. № 5. С. 20-42; № 6. С. 67-85.]

«Мертвые души» Гоголя как поэма дворянского возрождения.

[Впервые: В борьбе за марксизм в литературной науке: сб. статей / Ред. В. Десницкого, Н. Яковлева, Л. Цырлина. Л.: Прибой, 1930; см. также: Литературная учеба. Л., 1931. № 2. С. 50-66.]

Добужсинский М.В. О постановке «Ревизора» в Литовском государственном театре // Сегодня. Рига, 1933. 17 октября.

Ермилов В. «Мертвые души» в Художественном театре // Литературная газета. М., 1933. 5 января. № 1(229). С. 3-4.

Ермилов В.В. Театр и правда // Красная новь. М., 1933. № 2. С. 183-188.

[О постановке в МХАТе «Мертвых душ» Гоголя.]

Ермилов В. Театр и правда (К дискуссии о «Мертвых душах» на сцене МХАТ) // Известия. М., 1933. 27 февраля. № 57(4988). С. 2-3.

[В тексте шаржи Э. Мордмилловича: М.М. Тарханов в роли Собакевича, В.О. Топорков в роли Чичикова, И.М. Москвин в роли Ноздрева.]

Иорданский М., Козлов П., Таранущенко В. К проблеме советской оперы (Оперное творчество советских композиторов за 15 лет) // Советская музыка. М., 1933. № 1. С. 19-50. [В частности, «Нос» Д. Шостаковича.]

К.Ф. Исповедь Чичикова. «Серп и молот» обсуждает «Мертвые души» // Советское искусство. М., 1933. 14 января. № 3(119). С. 3.

Крестова Л.В. Комментарий к комедии Н.В. Гоголя «Ревизор». С полным текстом комедии. М.: Кооперативное изд-во «Мир», 1933. 135 с. - (Комментарии к памятникам художественной литературы / Под ред. Н.Л. Бродского и Н.П. Сидорова. Вып. 6).

Отд. 1:

1. Как писался «Ревизор». С. 3-6.

2. Гоголь Н.В. «Ревизор» (Полный текст). С. 9-70.

3. Словарь. С. 71-72.

Отд. 2:

Комментарий к комедии Гоголя. С. 73-112.

Отд. 3:

Зрители «Ревизора». С. 113-135.

[Рец.: Пиксанов Н.К. // Литературный Ленинград. Л., 1934. 31 марта. № 15.]

Кубиков И.Н. Классики русской литературы: Пушкин, Гоголь, Тургенев, Достоевский, Некрасов, Л. Толстой, Салтыков Щедрин, Гл. Успенский, Островский, Чехов и М. Горький: Лекции, читанные в Воскресном ун-те 1-го МГУ. М.: Изд-во 1-го Московского гос. ун-та, 1933. 295, [2] с.

Гоголь. С. 31-52.

Кугель A.P. (Hoто Novus). Русские драматурги: очерки театрального критика / Ред. и примеч. В.Ф. Боцяновского. М.: Мир, 1933. 179 с.

Из содерж.:

Загадка Гоголя С. 37-46.

М.Вл. «Ревизор» в театре русской драмы // Пролетарий. Харьков, 1933. 20 ноября. № 267(3061). C. 4.

Маркс, Энгельс, Ленин и Сталин об искусстве и литературе // Книга и пролетарская революция. М., 1933. № 8. С. 98-128.

[О Гоголе: С. 103-104.]

Мацуев H. Художественная литература в оценке периодической печати (Библиографический указатель) // Литературный критик. М., 1933. Кн. 4. С. 145-153. 
Млечин B. Непрочитанный Гоголь: «Мертвые души» в МХТ им. Горького // Рабис: журнал Всесоюзного профсоюза работников искусств. М., 1933. № 1. С. 25-26.

Некрасов А.И., проф. Рисунки Гоголя // СХУ заседание, организованное совместно с Государственным музеем изобразительных искусств. М., 1933. 7 июня. [4] с. - (Секция собирателей книг и экслибрисов МОВОФ [Московское отделение Всероссийского общества филателистов]).

[Тезисы доклада и факсимиле рисунков к последней сцене «Ревизора» Гоголя. См. также: $\mathrm{He-}$ красов А. Приписываемые Гоголю рисунки к «Ревизору» // Литературное наследство. М.: Журнально-газетное объединение, 1935. Кн. 19-21. С. 531-550.]

Никулин Л.В. Идеи и образы // Советское искусство. М., 1933. 26 января. № 5.

[О постановке «Мертвых душ» в МХАТе.]

Новиикий П. Современные театральные системы. М.: ГИХЛ, 1933. 244 с. - (Государственная театральная библиотека при Малом театре).

[О постановке «Женитьбы» Гоголя в театре им. Вахтангова 20 февраля 1924 г.: С. 148-150.]

Оружейников Н. О простоте и красочности // Советское искусство. М., 1933. 2 января. № 1. [О постановке «Мертвых душ» в МХАТе.]

$<$ Петров Н.В.> Выдержки из стенограммы экспозиционного доклада, прочитанного заслуженным деятелем искусств Н.В. Петровым труппе 15 сентября 1933 г. // Театр русской драмы. Харьков, 1933. 17 ноября. № 2. С. 2.

[К постановке «Ревизора» Гоголя.]

Петров Н. Образ Хлестакова (Из записной книжки исполнителя) // Театр русской драмы. Харьков, 1933. 17 ноября. № 2. С. 3.

Пиксанов Н.К. О классиках: сб. статей. М.: Московское товарищество писателей, 1933. $416 \mathrm{c}$.

Из содерж.:

Украинские повести Гоголя С. 43-148.

Примеч. С. 398-402.

Хронология украинских повестей Гоголя. С. 403-405.

[Рец.: Сергиевский И. // Литературный критик. М., 1933. № 2. С. 184-187; ответ Н.К. Пиксанова: Письмо в редакцию (Об отзывах И. Сергиевского и о самом себе) // Литературный критик. M., 1933. № 7. C. 212-217.]

Савелова 3., Ливанова Т. Указатель литературы о Н.А. Римском-Корсакове // Советская музыка. М., 1933. № 3. С. 188-194.

[C. 191: «Майская ночь», «Ночь перед Рождеством».]

Сергеев-Ценский С. Гоголь уходит в ночь. М.: Изд-во Советская литература, 1933. 278 с.

[Рец.: Периов В. // Литературный критик. М., 1934. № 2. С. 283-284; Литовщева К. <Богаевская К.П.> // Новый мир. М., 1934. № 9. С. 201-202; Вельс С. Очередное «биографическое» искажение // Художественная литература: критико-библиографический бюллетень. М., 1933. № 7. С. 27.]

Синельников Н.Н. Воспоминания и мысли // Театр русской драмы. Харьков, 1933. 17 ноября. № 2. С. 3.

[О постановке «Ревизора» Гоголя.]

Соболев Ю.В. М.С. Щепкин. М.: Журнально-газетное объединение, 1933. 159, [1] с.: ил. - (Жизнь замечательных людей: серия биографий. Вып. VIII).

[Гл. 3: Актер Гоголя. С. 105-122.]

Соболев Ю. «Мертвые души» в МХАТ СССР им. Горького // Труд. М., 1933. 17 января. № 15(3653). C. 4.

[В тексте шаржи: И.М. Москвин в роли Ноздрева и В.И. Топорков в роли Чичикова.]

Соболев Ю.В. Чичиков - Топорков, Собакевич - Тарханов, Ноздрев - Москвин // Рабис: журнал Всесоюзного профсоюза работников искусств. М., 1933. № 1. С. 25-27. 
[В тексте шаржи: В.И. Топорков в роли Чичикова и М.М. Тарханов в роли Собакевича.]

Тальников Д. «Мертвые души» в Художественном театре // Театр и драматургия. М., 1933. № 1. С. 55-60; № 2-3. С. 24-29.

[В тексте фотографии: И.М. Москвин в роли Ноздрева, Н.Л. Подгорный в роли прокурора, Л.М. Леонидов в роли Плюшкина, В.Я. Станицын в роли губернатора; сцены У Манилова, Бал у губернатора, Две дамы, Чичиков у Ноздрева, а также шесть сцен из постановки Александринского театра.]

Тинг. Московские спектакли. Девять заметок о «Мертвых душах» // 30 дней. М., 1933. № 1. С. 73-77.

[О постановке в МХАТе; с рисунками А. Костомолоцкого: Ноздрев (И.М. Москвин), у прокурора (Н.Л. Подгорный), встреча Чичикова (В.О. Топорков) с Собакевичем (М.М. Тарханов), Коробочка (А.П. Зуева).]

Фори О. Символисты: роман // Звезда. Л.; М., 1933. № 1, 5, 9, 10.

[В отдельном издании (Л., 1934) роман озаглавлен «Ворон».]

[А.А. Иванов и Гоголь.]

Ш.И. Н.В. Гоголь (Биографическая справка) // Театр русской драмы. Харьков, 1933. 17 ноября. № 2. С. 1.

Шестидесятые годы. М.А. Антонович. Воспоминания. Г.3. Елисеев. Воспоминания / Ред., вступ. статьи и коммент. В. Евгеньева-Максимова и Г.Ф. Тизенгаузена. М.; Л.: Academia, 1933. 578, [4] с.: ил. - (Русские мемуары, письма и материалы).

[Указ. имен.]

<Щепкин М.С.> Записки актера Щепкина / Предисл., примеч. и статья А.Б. Дермана. Переработ, и доп. изд. с приложением рассказа В.А. Соллогуба «Собачка». М.; Л.: Academia, 1933. 398, [4] с.: ил. - (Театр / Под общ. ред. А.К. Дживелегова).

Из содерж.:

Черты из биографии и творчества М.С. Щепкина (Щепкин и Гоголь). С. 295-306.

Дерман А.Б. Предисловие к рассказу В.А. Соллогуба «Собачка». С. 194.

\section{4}

\section{ПРОИЗ В ДЕНИЯ}

Вечера на хуторе близ Диканьки. Миргород / Биографический очерк Н.С. Ашукина.; примеч. Б.Х. Черняка. М.: ГИХЛ, 1934. 469 с. - (Дешевая библиотека ОГИЗ). 75000 экз.

Детство Чичикова. М.: ГИХЛ, 1934. 23 с. - (Библиотека начинающего читателя). 100000 экз.

Мертвые души: поэма / Предисл. Л.Б. Каменева; рис. А.А. Агина. [М.:] ГИХЛ, 1934. 433, [2] с.; ил. 15000 экз.

[Предисл. Л.Б. Каменева. С. 5-16 - удалено цензурой. В тексте 72 иллюстрации А.А. Агина.] [Рец.: Г.Л. // Комсомольская правда. М., 1934. 29 марта. № 75. С. 4.]

Мертвые души: поэма / Ил. А.А. Агина; примеч. Б.Х. Черняка. М.; Л.: Гослитиздат, 1934. 368 с. - (Дешевая библиотека. Книгу - социалистической деревне). 50000 экз.

[Рец.: Варшавский Л. Новое издание «Мертвых душ» Гоголя // Книга и пролетарская революция. М., 1934. № 5. С. 57-58; Л.Г. // Комсомольская правда. М., 1934. 29 марта. № 75. С. 4; Переверзев В. Горе-комментаторы // За коммунистическое просвещение. М., 1934. 17 октября № 240(1711). С. 3.]

Мертвые души: поэма / Ред. и примеч. Б.Х. Черняка. М.: Детгиз, 1934. 416 с. - (Школьная серия классиков). 50000 экз.

[Рец.: Рыббикова М.А. // Детская и юношеская литература. 1934. № 9. С. 25-27; Переверзев В.Ф. // За коммунистическое просвещение. М., 1934. 17 октября. № 240(1711). С. 3.] 
«Москва и Петербург» (Из записок дорожного) / Публ. и коммент. Ю.Г. Оксмана // Литературный Ленинград. Л., 1934. 31 марта. № 15. С. 3.

[Доцензурная редакция начала «Петербургских записок 1836 года» Гоголя.]

Письмо Н.В. Гоголя к А.О. Смирновой / [Публ. В.В. Гиппиуса.] // Литературный Ленинград. Л., 1934. 31 марта. № 15(37). С. 3.

[Письмо от 15 февраля (н. ст.) 1844 г., Ницца.]

Собрание сочинений / Биографический очерк Н.С. Ашукина; вступ. статья А.В. Луначарского; худож. А.А. Толоконников М.. ГИХЛ. 1934. ХХІ, [2], 673, [1] с. 30000 экз.

\section{ЛИТ Е РАТ У РА}

Агеев И. Да, но где же достать Гоголя // За индустриализацию. М., 1934.2 апреля. № 78. С. 3. [О необходимости выпустить удешевленное издание сочинений Гоголя.]

A.M. Николай Васильевич Гоголь // Рабочий путь. Смоленск, 1934. 1 апреля.

Адамович Г. Андрей Белый и Гоголь // Последние новости. Париж, 1934. 14 июня. № 4830 .

[Перепечатано: Трудный Путь. Зарубежная Россия и Гоголь / Сост., вступ. статья и коммент. М.Д. Филина. М.: Русскій Мірь, 2002. С. 77-83.]

Анисимов С. Как Гоголь собирал материалы для своих произведений (К 125-летию со дня рождения Н.В. Гоголя) // Звезда Севера. Архангельск, 1934. № 3. С. 56-64.

$<$ Антоновский Б., Флит А.> После «Женитьбы». Шарж Б. Антоновского. Стихи А. Флита // Красная газета (вечерн. вып.). Л., 1934. 22 апреля. № 93(4073).

Б.А. Дом, в котором умер Н.В. Гоголь // Литературная газета. М, 1934. 28 марта. № 38(364). C. 4 .

Белинский В.Г. Избранные сочинения: В 3 т. Т. І. / Вступ. статья Ф.М. Левина; ред. текста Д. Благого; коммент. Д. Благого и А. Лаврецкого. М.: ГИХЛ [Гос. изд-во художественной литературы], 1934. XXXVII, 608 с.

Из содерж.:

О русской повести и повестях г. Гоголя. С. 76-118.

Коммент. С. 570-572.

[Рец.: Виноградова О. // Правда. М., 1934. 22 ноября. № 321. С. 4.]

Бельй А. Мастерство Гоголя: Исследование / Предисл. Л. Каменева. М.; Л.: Гос. изд-во художественной литературы [ГИХЛ], 1934. XVI, 324 с.: 13 л. ил. и схем.

Предисл. С. V-XIII.

[I. Творческий процесс Гоголя. II. Сюжет Гоголя. III. Изобразительность Гоголя. IV. Стиль прозы Гоголя. V. Гоголь в XIX и в XX вв.]

[Рец.: Тимофеев Л. Литературоведческий опыт символиста // Критико-библиографическнй бюллетень «Художественная литература». М., 1934. № 12. С. 55-58.]

[Переиздано: Бельй А. Мастерство Гоголя: Исследование / Предисл. Н. Жуковой. М.: МАЛП, 1996. 351 с.: ил.; Бельцй А. Мастерство Гоголя. Исследование / Вступ. статья Ю. Манна. М.: Книжный Клуб Книговек, 2011. 416 с.: ил.; Белый А. Собрание сочинений. Мастерство Гоголя: Исследование / Общ. ред., сост., послесл. и коммент. Л.А. Сугай. М.: Республика; Дмитрий Сечин, 2013. 559 с.: ил.]

Березарк И. «Женитьба» в Гос. театре драмы // Рабочий и театр. Л., 1934. № 12. С. 10-11.

Беседы с начинающими писателями: итоги двухлетней работы [1932-1934]. К всесоюзному съезду советских писателей / Институт русской литературы (Пушкинский Дом). Л.: Изд-во Академии наук СССР, 1934. 48 с.

[О докладе В. Гиппиуса «Работа Гоголя над созданием характера Хлестакова»: С. 35-37.]

Бицилли П. Гоголь и классическая комедия // Числа. Париж, 1934. № 10. С. 198-199. 
Бицилли П. Гоголь и Чехов (Проблема классического искусства) // Современные записки. Париж, 1934. № 56. С. 298-308.

[Перепечатано: Трудный Путь. Зарубежная Россия и Гоголь / Сост., вступ. статья и коммент. М.Д. Филина. М.: Русскій Міръ, 2002. С. 84-97.]

Бицилли П.М. Краткая история русской литературы. Ч.2: От Пушкина до нашего времени. София: Изд-во Н.Н. Алексеева, 1934.

Бицилли П.М. [Рецензия] // Путь. Париж, 1934. № 45. С. 77-79.

[Рец. на кн.: Мочульский К. Духовный путь Гоголя. YMCA PRESS. 1934.]

Бицилли П. Справка [По поводу кн. Б. Шлецера о Н. Гоголе на франц. яз.] // Встречи. Париж, 1934. № 2. С. 85.

Бондарев Д. Ревизор своего класса. К 125-летию со дня рождения Н.В. Гоголя // Звено. Иваново, 1934. № 3. С. 74-84.

Браун М. «Черевички». Опера Чайковского // Саратовский рабочий. Саратов, 1934. 10 января.

Бродский Н., проф. Гоголь (1809-1934) // Экономическая жизнь. М., 1934. 29 марта. № 73(4654). C. 4.

B.M. 125 лет со дня рождения Гоголя // Наступление. Смоленск, 1934. № 3. С. 98-99.

Варшавский Л. Новое издание «Мертвых душ» Гоголя // Книга и пролетарская революция. Книга и пролетарская революция. М., 1934. № 5. С. 57-58

Вебер E.C. В пустом и страшном мире: доклад, прочитанный в Русской драматической студии 22 апреля 1934 г. // Меч. 1934. № 8. С. 3-7.

Вейдле В. // [Рецензия] // Современные записки. Париж, 1934. № 54. С.

[Рец. на кн.: Gorlin M. N.V.Gogol und E.Th. Hoffmann.]

Вересаев В.В. Как работал Гоголь. 2-е изд. М.: Кооперативное изд-во «Мир», 1934. 82 с. (Как работали классики).

Вернер B. 10 заповедей смекалистого: Конспект повести для будущего Гоголя // За индустриализацию. М., 1934. 30 марта. № 76.

Верховский Н. [Рецензия] // Красная газета (вечерн. вып.). Л., 1934. 31 марта. № 74.

[Рец. на кн.: Данилов С.С. «Ревизор» на сцене / Предисл. Н.В. Петрова. Харьков: Изд. Харьковского гос. театра русской драмы, 1933. 144 с.: ил. - (Библиотека Харьковского гос. театра русской драмы. Вып. 2: К премьере спектакля «Ревизор» в ноябре 1933 г.).

Веселовский Т.Т. Н.В. Гоголь. 1809-1934 // Ленинградская правда. Л., 1934. 30 марта. № 76. C. 4 .

Вечер, посвященный Гоголю в ИРЛИ Академии наук СССР // Ленинградская правда. Л., 1934. 1 апреля. № 77. С. 4.

Виноградов В.В. Очерки по истории русского литературного языка XVII-XIX вв.: пособие для высших педагогических учебных заведений. М.: Гос. учебно-педагогическое изд-во, 1934. 288 с.

Язык Гоголя и его значение в истории русской литературной речи XIX в. С. 225-227.

Вишневский В.С. Гоголь и военная Россия // Литературный критик. М., 1934. № 4. C. 49-66. 
Войтович В. (завод «Промтехника»). О дружбе парторгов с Гоголем // Ленинградская правда. Л., 1934. 18 июня. № 142(5821). С. 3.

[О необходимости чтения художественной литературы для рабочих партийцев.]

Воронский А. Гоголь. <М.:> Журнально-газетное объединение, 1934. - (Серия Жизнь замечательных людей. Вып. XVIII-XVIII). 412 с.: ил.

[Отдельные главы переизданы: Воронский А.К. Избранные статьи. М., 1982; Воронский А.К. Искусство видеть мир. М., 1987; репринтное изд. / Предисл. Т.И. Исаевой <М., 2008.> 100 экз.; см. также: Воронский А.К. Гоголь / Вступ. статья В.А. Воропаева. М.: Молодая гвардия, 2009. 447 [1] с.: ил. (Жизнь замечательных людей: Малая серия: сер. биографий; вып. 1); Загл. вступ. статьи: Забытая книга. Об Александре Воронском и его «Гоголе». С. 5-16; 2-е изд. М.: Молодая гвардия, 2011. 447, [1] с.: ил. - (Жизнь замечательных людей: Малая серия: сер. биографий; вып. 24).]

Г.В. Иллюстраторы Гоголя // Резец: литературно-художественный журнал. Л., 1934. № 6. C. 23-24.

[Со снимками рисунков А.А. Агина к «Мертвым душам».]

Ганжулевич T. Н.В. Гоголь (125 лет со дня рождения) // Пролетарий. Харьков, 1934. 30 марта. № 74.

Гард Э. Гоголь и Пушкин вновь встречаются // Резец: литературно-художественный журнал. Л, 1934. № 6. С. 1-2.

[О потомках Гоголя и А.С. Пушкина.]

Гиппиус В. Академическое издание Гоголя // За социалистическую науку: орган парткома, президиума и месткома Академии наук. Л., 10 мая. № 13.

[Перепечатано: Красная газета (вечерн. вып.). Л., 1934. 23 мая.]

Гиппиус В., проф. Новое о Гоголе // Литературная газета. М 1934. 30 марта. № 39(355). С. 2. [Обзор неизданных материалов по Гоголю (тексты, письма и пр.), намеченных к опубликованию в Гоголевском сборнике Института русской литературы (Пушкинский Дом) Академии наук.]

Гиппиус B.В. Образы Гоголя у Ленина и Сталина // Советская Украина. Киев, 1934. 30 марта. № 73.

Гиппиус В. Неизданные письма Гоголя // Литературный Ленинград. Л., 1934. 31 марта № 15(37). C. 3.

[Обзор неопубликованных писем Гоголя, хранящихся в Пушкинском Доме (ИРЛИ).]

Глаголь С. Гоголевский спектакль // Пролетарий Осетии. Орджоникидзе, 1934. 30 марта. [О постановке «Ревизора» в городском театре.]

Гоголевская выставка // Ленинградская правда. Л., 1934. 6 мая. № 106. С. 4.

[О выставке в Русском музее «Герои Гоголя в изобразительном искусстве».]

Гоголевские дни в Ленинграде // Смена. Л., 1934. 29 марта. № 73. С. 4.

Гоголевские дни в Ленинграде // Комсомольская правда. М., 1934. 29 марта. № 75. С. 4.

Гоголевские дни в Ленинграде // Известия. М., 1934. 30 марта.

Гоголевские дни в Ленинграде // Красная газета (вечерн. вып.). Л., 1934. 23 апреля.

Гоголевские дни в Ленинграде (выставка) // Красная газета (вечерн. вып.). Л., 1934. 1 апреля. № 75. С. 2.

[О гоголевской выставке в музее Института русской литературы Академии наук СССР.]

Гоголевские дни в Москве // Комсомольская правда. М., 1934. 20 марта. № 67. С. 4.

Гоголевские традиции и живой Гоголь // Рабочий и театр. Л., 1934. № 10.

[Гоголь и советская драматургия.] 
Гоголевские реликвии // Красная газета (веч. выпуск). Л., 1934. 24 июня. № 37. С. 1. [О передаче в Полтавский музей рисунков и переписки Гоголя с матерью и теткой.]

Гоголевский вечер в Чеховской библиотеке в Таганроге // Таганрогская правда. Таганрог, 1934. 3 апреля.

Гоголевский спектакль в театре драмы. // Красная газета (утрен. вып.). Л., 1934. 2 апреля. № 76.

Гоголевский спектакль. Вчера в театре Госдрамы // Красная газета (вечерн. вып.). Л., 1934. 14 апреля. № 86.

<Гоголь Н.В.> Н. Гоголь (К 125-летию со дня рождения) // Правда Востока. Ташкент, 1934. 14 апреля. № 86(3445). С. 3-4.

$<$ Гоголь Н.В.> Н. Гоголь (К стодвадцатипялетию со дня рождения) // Правда Востока. Ташкент, 1934. 14 апреля. № 86(3445). С. 3-4.

$<$ Гоголь Н.В.> Н.В. Гоголь в портретах и иллюстрациях / Текст Д.Н. Николаева. Л.: Издание горкома писателей, 1934. 19 с.: ил. - (Писатели в портретах и иллюстрациях). [19 репродукций.]

$<$ Гоголь Н.В.> Н.В. Гоголь (К 125-летию со дня рождения) // Уральский рабочий. Свердловск, 1934. 30 марта. № 75(5609). С. 4.

$<$ Гоголь Н.В.> Н.В. Гоголь (К стодвадцатипялетию со дня рождения) // Рабочий путь. Омск, 1934. 10 апреля.

Головенченко Ф.М. Величие Гоголя // Вечерняя Москва. М., 1934. 29 марта. № 73(3102). C. 3 .

Головенченко Ф. Н.В. Гоголь и Украина. К 125 -летию со дня рождения писателя // Просвещение национальностей. М., 1934. № 3. С. 53-57.

Головенченко Ф.М. Н.В. Гоголь (К 125 -летию со дня рождения) // За Коммунистическое просвещение. М., 1934. № 3. С. 57-67.

Головенченко Ф. проф. «Ревизор» Н.В. Гоголя (К столетию начала драматургической деятельности великого писателя) // За коммунистическое просвещение. М., 1934. 1 апреля. № 75(1546). С. 3.

Гофман В.А. О литературном языке (Язык «Ревизора») // Литературная учеба. Л., 1934. № 6. C. 74-101.

Гус М. Рассказ о том, как поссорились... // Тридцать дней. М., 1934, № 11. С. 68-73.

[Столкновение уходящего дворянства с нарождающейся буржуазией в творчестве Гоголя.]

Д.Н. Из опыта Н.В. Гоголя // Резец: литературно-художественный журнал. Л., 1934. № 6. C. 21-23.

Данилов В.В. Следы творчества Н.В. Гоголя в очерке П.П. Свиньина «Полтава» // Сборник статей к 40-летию ученой деятельности акад. А.С. Орлова / Академия наук СССР. Институт русской литературы. Л.: Изд-во АН СССР, 1934. С. 39-44.

Данилов С. Городничие и Хлестаковы. К сценической истории «Ревизора» // Советское искусство. М., 1934. 29 марта. № 15(181). С. 3. 
Данилов С.С. «Женитьба» Н.В. Гоголя. Л.: Гос. академический театр драмы, 1934. 133, [1] с.: ил.

[Работа Гоголя над «Женитьбой». Сценическая история пьесы. В примечаниях дана библиография литературы о постановках «Женитьбы».]

Данилов С.С. «Женитьба» на сцене // CXXV. Н.В. Гоголь. 1809-1934 / Гос. академический театр драмы. Л., 1934. С. 2-5.

[C. 1: Программа совместного торжественного заседания ИРЛИ Академии наук СССР, Гос. Академии искусствознании и Гос. академического театра драмы и спектакля «Женитьба».]

Данилов С.С. «Ревизор» на сцене. 2-е изд., испр. и доп., с приложением монтировки первого спектакля / Гос. академия искусствознания. Л.: Гос. изд-во художественной литературы [ГИХЛ], 1934. 148 с: ил.

\section{Содерж:}

Предисловие ко второму изданию. С. 3-4.

Петров Н. Предисловие к первому изданию. С. 5-8.

І. Введение. С. 11-13.

II. «Владимир 3-й степени» как первый драматургический опыт Гоголя. С. 13-15.

III. История сюжета «Ревизора». С. 15-17.

IV. Комедия Квитки-Основьяненко «Приезжий из столицы» и «Ревизор» Гоголя. С. 18-20.

V. «Ревизор» и «натуральная школа». С. 20-21.

VI. Хронология работы Гоголя над «Ревизором». Редакции и варианты комедии. С. 21-23.

VII. Творческая эволюция «Ревизора». С. 23-26.

VIII. «Ревизор» как социальная сатира. Историческое значение комедии. С. 26-27.

IX. Первое представление «Ревизора». С. 27-34.

Х. Постановка «Ревизора» на московской сцене. С. 34-37.

XI. «Настоящий ревизор» Цицианова - «продолжение» комедии Гоголя. С. 37-40.

XII. «Ревизор» в исполнении писателей. С. 40-43.

XIII. Первые постановки «Ревизора» по окончательной редакции комедии. С. $43-47$.

XIV. «Ревизор» на провинциальной сцене. С. 47-52.

XV. «Ревизор» и «народный театр». С. 52-54.

XVI. Пятидесятилетний юбилей «Ревизора». Новая постановка «Ревизора» в Александринском театре в 1897 г. С. 54-56.

XVII. «Ревизор» в постановке Гнедича. С. 56-59.

XVIII. Первая постановка «Ревизора» в МХТ. С. 59-65.

XIX. Эволюция основных актерских образов комедии на дореволюционной сцене. С. 65-71.

XX. «Ревизор» в подражаниях и пародиях дореволюционного театра. С. 71-72.

XXI. Первые постановки «Ревизора» на советской сцене. С. 72-76.

ХХІІ. Новая постановка «Ревизора» в МХТ. Чехов - Хлестаков. С. 76-81.

XXIII. Попытки приспособления комедии Гоголя к современности. С. 81-84.

XXIV. «Ревизор» в театре МГСПС. С. 84-87.

XXV. Экспериментальная постановка «Ревизора» в Театре-студии Акдрамы. Новая постановка в Акдраме. С. 87-91.

XXVI. «Ревизор» в театре им. Мейерхольда. С. 92-100.

XXVII. Рецидивы театрального футуризма и комедия Гоголя. С. 100-104.

XXVIII. «Ревизор» в современных подражаниях и пародиях. С. 104-105.

XXIX. Новые постановки «Ревизора» на советской сцене. С. 105-109.

$\mathrm{XXX}$. Итоги сценической истории «Ревизора». Основные задачи критического освоения комедии Гоголя современным советским театром. С. 109-113.

Примечания. С. $114-126$.

Приложение I: Монтировка первой постановки «Ревизора» на сцене Александринского театра в 1836 г. С. 127-142.

Приложение II: Сравнительная таблица постановок «Ревизора» на различных этапах его сценической истории. С. 143-144.

Перечень иллюстраций. С. 145-146. 
Данилов С.C. Торжественный спектакль в ознаменование 125 -летия со дня рождения Николая Васильевича Гоголя (1809-1934): программа. «Женитьба» на сцене. [Л.: Гос. академический театр драмы, 1934]. 4 с.

Дмитриев О. Великий сатирик // Пролетарий Осетии. Орджоникидзе, 1934. 30 марта. [О Гоголе.]

Добролюбов Н.А. Полное собрание сочинений: В 6 т. / Под общ. ред. П.И. Лебедева-Полянского; [вступ. статья М. Клевенского] Т. 1. М.: ГИХЛ, 1934.

Загл. вступ. статьи: Н.А. Добролюбов.

Александр Сергеевич Пушкин. С. 117-118.

«Мишура». Комедия в 4-х действиях Алексея Потехина $<$ Отрывок $>$. С. 507-509.

[Впервые: Современник. 1858. № 8. С. 203-231. Печ. по изд.: Добролюбов Н.А. Полное собрание сочинений: В 6 т. / Под общ. ред. П.И. Лебедева-Полянского. Т. 1. М.: ГИХЛ, 1934. С. 422-423.]

Др. С. Театры обошли молчанием гоголевские дни в Ленинграде // Красная газета (вечерн. вып.). Л., 1934. 3 апреля. № 77(4057). С. 2.

[С карикатурой: Хроника гоголевских дней. Рис. А. Антоновского.]

Дурылин С. Гоголь-актер // Театр и драматургия. М., 1934. № 5(14). С. 52-59.

Дурылин С.Н. Гоголь и Аксаковы (С тремя неизданными записками Гоголя) // Звенья: сб. материалов и документов по истории литературы, искусства и общественной мысли XIX века. Т. 3-4. Л.; М.: Academia, 1934. С. 325-364.

[Неизданные записки Гоголя к Аксаковым: С.Т. Аксакову (1848 г.), К.С. Аксакову (1850 г.) и О.С. Аксаковой (1850-1852 гг.): С. 352, 360, 363.]

Дурылин С. Задушенная комедия Гоголя // Литературная газета. М., 1934. 30 марта. № 39. C. 3 .

[О комедии «Владимир 3-й степени».]

Дурылин С. Смех на сцене (Судьба русской комедии) // Советское искусство. М., 1934. 17 апреля. № 18(184). С. 2.

Евгеньев-Максимов В.E. «Современник» в 40-50 гг.: От Белинского до Чернышевского. Л.: Изд-во писателей в Ленинграде, 1934. 454 с.

[Критические статьи о «Мертвых душах», «Выбранных местах из переписки с друзьями»; письмо В.Г. Белинского к Гоголю и др.]

[Указ. имен.]

Ефремин А. Н.В. Гоголь (к 125-летию со дня рождения) // Комсомольская правда. М., 1934. 29 марта. № 75(2768). С. 3.

Ефремин A. Н.В. Гоголь (к 125-летию со дня рождения) // Таганрогская правда. Таганрог, 1934. 3 апреля. № 77(3687). С. 3.

«Женитьба» в Госдраме // Красная газета (вечерн. вып.). Л., 1934. 11 апреля. № 84. С. 2.

«Женитьба» в Ленинградской Госдраме // Вечерняя Москва. М., 1934. 17 марта.

Жизнь и творчество Н.В. Гоголя // Молодой сталинец. Саратов, 1934. 18 сентября. № 190. [Хронологическая канва.]

Загорский М. Гоголь и Щепкин // Литературная газета М., 1934. 30 марта. № 39(355). С. 3.

Загорский М. Неизданные рисунки Боклевского к «Ревизору» // Театр и драматургия. М., 1934. № 8. С. 50-55: ил.

Загорский М. Театр Гоголя (К 125-летию со дня рождения Н.В. Гоголя) // Вечерняя Москва. М., 1934. 29 марта. 
Записная книжка Гоголя // Литературная газета. М., 1934. 14 февраля. № 17(332). С. 4. [В Рукописный отдел Публичной библиотеки СССР им. В.И. Ленина поступила записная книжка Гоголя начала 1840 -х гг.]

Записная книжка Гоголя // Литературная газета. М., 1934. 30 марта. № 39(355). С. 2. [Со снимками переплета книжки и двух рисунков Гоголя, впервые воспроизводимых в печати.] Заславский Д. Гоголь (К стодвадцатипятилетию со дня рождения) // Правда. М., 1934. 27 марта. № 85(5971). С. 2.

Заславский Д. Н.В. Гоголь (К 125-летию со дня рождения) // Заря Востока. Тифлис, 1934. 30 марта. № 76(3187). С. 3.

Игорев Н. Смех - великое дело // За индустриализацию. М., 1934. 30 марта. № 76(3742). C. 2.

[О Гоголе.]

Из неизданных рисунков Гоголя // Литературная газета. М., 1934. 30 марта. № 39(355). C. 2.

Ильинский А. Как был сожжен «Выбритый ус» Гоголя // Смена. Л., 1934. 2 апреля. № 76(2699).

[Иллюстрации П.М. Боклевского к «Ревизору»] // Театр и драматургия. 1934. № 8.

К. Н.В. Гоголь // Легкая индустрия. М., 1934. 30 марта. № 74(650). С. 4.

К юбилею Гоголя // Литературная газета. М., 1934. 26 марта. № 37. С. 1.

[Об издании Ленизогизом историко-литературных таблиц с портретами и иллюстрациями, посвященными Гоголю.]

Камегулов А. Трагедия Гоголя // Литературный Ленинград. Л., 1934. 31 марта. № 15(37).

Камегулов А. Трагедия Гоголя // Литературная учеба, Л., 1934. № 3. С. 10-33.

Камегулов A. Трагедия Гоголя // Резец: литературно-художественный журнал. Л., 1934. № 6. C. $18-19$.

Клеман М. Гоголь о художественном творчестве (По материалам переписки) // Литературная учеба, Л., 1934. № 4. С. 48-61.

Кольский Г. Жизнь и смерть Гоголя // Северный комсомолец. Архангельск, 1934. 12 июля.

Константинов Н. «Женитьба» на сцене Госдрамы // Красная газета (утрен. вып.). Л., 1934. 16 апреля. № 88. С. 4.

Лапидус М. Проект города Маниловска // За индустриализацию. М., 1934. 30 марта. № 76 .

Левин М. «Женитьба» (Ростовский театр юных зрителей) // Молот. Ростов-на-Дону, 1934. 3 апреля.

Лернер Н. Гоголь над бездною: пьеса в пяти действиях и десяти картинах / Всекдрам, отдел распространения; предисл. Р.А. Пельше. М., 1934. 94 с. 1000 экз. (на правах рукописи).

[Рец.: Мазинг Б. Красная газета (вечерн. вып.). Л., 1934. 15 мая. № 110.]

Литературное наследство. Т. 13-14: М.Е. Салтыков-Щедрин. Кн. 2 / Отв. ред. Л. Авербах. М.: Журнально-газетное объединение, 1934. ХХ, 721 с.: ил.

Из содерж.: 
Калаушин М.М. Салтыков в лицее. С. 463-480.

[О постановке в Царскосельском лицее 19 октября 1842 г. двух сцен из «Мертвых душ» Гоголя: C. 478.]

Литературный Ленинград. Л., 1934. 30 марта.

[Юбилейный гоголевский номер.]

Луначарский А.В. Гоголиана: Николай Васильевич приготовляет макароны // Известия. М., 1934. 2 апреля. № 78(5326). С. 3-4.

[Фельетон.]

М.Э. Н.В. Гоголь (К 125-летию со дня рождения) // Маяк коммуны. Севастополь, 1934. 30 марта. № 73(4095). С. 3.

Мазинг Б. Расправа над классиками или историческая драматургия Лернера (Н.Н. Лернер. «Чернышевский и Александр ІІ», «Гоголь над бездной». М., Изд-во Всекдрам) // Красная газета (вечерн. вып.). Л., 1934. 15 мая. № 110(4090). С. 2.

Маиуев Н. Библиографическая справка (Издания Гоголя и литература о Гоголе) // Книга и пролетарская революция. М., 1934. № 5. С. 58-60.

Маиуев H. Новые книги по критике и литературоведению (январь-июнь 1934 г.) // Литературный критик. М., 1934. № 7-8. С. 291-301.

[О Гоголе: С. 297.]

Маиуев Н. Три года советской литературы. Изд-во Советская литература. М., 1934. 115 с. [Библиография 1931-1933 гг.]

Мережковский Д. Гоголь и Россия // Возрождение. Париж, 1934. 10 июня. № 3294.

Мочульский К. Духовный путь Гоголя. Paris: YMCA-PRESS, 1934. 150 c.

[Переиздано: Мочульский К. Духовный путь Гоголя. 2-е изд. Paris: YMCA-PRESS, 1976. 147 с.; Мочульский К. Гоголь. Соловьев. Достоевский / Сост. и послесл. В.М. Толмачева; примеч. К.А. Александровой. М.: Республика, 1995. С. 6-60.]

[Рец.: Бицилли П.М. // Путь. Париж, 1934. № 45. С. 77-79; Вышеславиев Б. // Современные записки. Париж, 1934. № 56. С. 427-430; Рудинский В. // Современник. Торонто, 1980. № 47/48. C. 161-163; Обухов В. «Гоголь, Соловьев, Достоевский». Этапы духовного развития русской литературы // Русская мысль. Париж, 1995. № 4103. С. 13; Козырев А. // Новый мир. М., 1996. № 8. С. 241-242; Обухов В. Две трилогии о русской литературе // Литературное обозрение. М., 1997. № 6. С. 64-66, Паламарчук П. Москва или Третий Рим? Восемнадцать очерков о русской истории и словесности. М., 1991. С. 20. Реф.: Сохряков Ю.И. // Литературная энциклопедия русского зарубежья (1918-1940) / РАН ИНИОН. Т. 3. Ч. 2. М., 1999. С. 217-220.]

Мышковская Л. Литературные проблемы пушкинской поры. М.: Советская литература, 1934. 186, [2] c.

[О Гоголе: С. 44, 75-77, 175.]

Мышковская Л. Особенности гоголевского стиля // Рост. М., 1934. № 9. С. 52-57.

Найдены автографы Гоголя // Правда. М., 1934. 11 ноября. № 310. С. 6.

[Об автографах, переданных из библиотеки Нежинского пед. ин-та в библиотеку Всеукраинской Академии наук.]

Накануне гоголевского юбилея // Литературная газета. М., 1934. 26 марта. № 73. С. 1. [Об академическом издании сочинений Гоголя, издании Гоголевского сборника и о проведении юбилейных мероприятий в Ленинграде, посвященных 125-летию со дня рождения писателя.]

Неизвестная страница Гоголя // Литературный Ленинград. Л., 1934. № 15.

[О постановке «Мертвых душ» Гоголя В.В. Чуйко в Гос. литературном музее] // Комсомольская правда. М., 1934. 20 марта. № 67. 
Париэт Вл. Н.В. Гоголь (К 125-летию со дня рождения) // Армавирская коммуна. Армавир, 1934. 8 апреля. № 82(2952).

Переверзев В. Гоголь и театр // Советское искусство. М., 1934. 23 марта. № 14.

Переверзев В. Горе-комментаторы // За коммунистическое просвещение. М., 1934. 17 октября № 240(1711). С. 3.

[О комментариях Б.Х. Черняка к «Мертвым душам» (М.; Л.: Гослитиздат, 1934).]

Переверзев В. Народный язык у Гоголя // Литературный критик. М., 1934. № 9. С. 80-93. [Откл.: Тимофеев Л. Итоги съезда и критика // Книга и пролетарская революция. М., 1934. № 12. C. 96.]

Перельман М. Фантастика и реальность // Резец: литературно-художественный журнал. Л., 1934. № 6. С. 20.

[О творческом методе Гоголя.]

Пиксанов Н., проф. Борьба за Гоголя // Красная газета (вечерн. вып.). Л., 1934. 31 марта. № 74. C. 2.

Пиксанов Н. Между двух миров. Писательская драма Гоголя // Смена. Л., 1934. 1 апреля. № 75(2698). С. 3.

Пиксанов Н. [Рецензия] / Литературный Ленинград. Л., 1935. 31 марта. № 15.

[Рец.: на кн.: Данилов С.С. «Ревизор» на сцене / Предисл. Н.В. Петрова. Харьков: Изд. Харьковского гос. театра русской драмы, 1933. 144 с.: ил. - (Библиотека Харьковского гос. театра русской драмы. Вып. 2: К премьере спектакля «Ревизор» в ноябре 1933 г.).]

$<$ Пиксанов Н.К.> Что читать о Гоголе // Смена. Л., 1934. 27 марта. № 71(2694). С. 4; 28 марта. № 72 (2695); 29 марта. № 73 (2696); 30 марта. № 74 (2697).

Пиотровский А. «Женитьба». Гоголевский спектакль в Госдраме // Красная газета (вечерн. вып.). Л., 1934. 21 апреля. № 92. С. 2.

Полнер Т.В. [Рецензия] // Современные записки. Париж, 1934. № 56. С. 430-432.

[Рец. на кн.: Вересаев В. Гоголь в жизни. М.; Л.: Academia, 1933.]

Рождественская К. Русские классики за работой // Штурм. Свердловск, 1934. № 10. C. $104-115$.

Гл. 1: Труд и вдохновение. С. 104-106.

Рукописи Гоголя передаются в ВУАН // Известия ЦИК СССР и ВЦИК. М., 1934. 4 декабря. № 282. С. 4.

[О передаче рукописей Гоголя («Портрет», «Тарас Бульба» и др.) из Нежинского пед. ин-та во Всеукраинскую академию наук.]

Северянин И. Гоголь // Северянин И. Медальоны. Сонеты и вариации о поэтах, писателях и композиторах. Белград, изд. автора, 1934.

[Перепечатано: Трудный Путь. Зарубежная Россия и Гоголь / Сост., вступ. статья и коммент. М.Д. Филина. М.: Русскій Міръ, 2002. С. 68.]

Семенов Л. Гоголь в работах Ленина // Пролетарий Осетии. Орджоникидзе, 1934. 30 марта.

Семенов-Тян-Шанский В.П. Памяти Гоголя, первого глашатая у нас правильных идей школьной географии // География в школе. 1934. № 1. С. 19-21.

Сергеев-Ценский С.Н. Гоголь уходит в ночь: повесть. М.: Московское товарищество писателей, 1934. 126 с.: ил.

Сергиевский И. [Рецензия] // Литературная газета. М., 1934. 12 апреля. № 145. 
[Рец. на кн.: Вересаев В.В. Как работал Гоголь. М.: Кооперативное изд-во Мир, 1932. 80 с. - (Как работали классики / Ред. серии Д.Д. Благой. Вып. 1).]

Слонимский А. Гоголь и театр // Рабочий и театр. Л., 1934. № 10. С. 2-5.

Смирнова-Чикина Е.С. Комментарий к поэме Гоголя «Мертвые души». М.: Мир, 1934. 174 с. - (Комментарий к памятникам художественной литературы. Вып. 7).

Соллертинский И. Гоголь в русской опере // Рабочий и театр. Л., 1934. № 10. С. 6-7.

Станица. Париж, 1934. № 10.

[К 125-летию со дня рождения Гоголя. Потомки Гоголя и Пушкина за рубежом.]

Старчаков А.О. Творчество и проповедь (К 125-летию со дня рождения Гоголя) // Известия. М., 1934. 29 марта. № 75. С. 4.

Стеффен Г. О «Ревизоре» // Звезда Севера. Архангельск, 1934. № 4. С. 58-61.

[О постановке в Большом Архангельском театре «Ревизора» Гоголя.]

125 лет жизни Н.В. Гоголя // Атака: литературно-художественный журнал красноармейского творчества. Ташкент, 1934. № 1. С. 53.

125-летие со дня рождения Гоголя // Красная газета (вечерн. вып.). Л., 1934. 27 марта. № 71 . C. 3.

[О собрании, посвященном Гоголю, в ленинградском Доме ученых.]

Тамарченко Д. Мировоззрение и метод в художественном творчестве // Звезда. Л., 1934. № 6. C. $152-165$.

[О противоречии между художественным методом и мировоззрением Гоголя.]

Тургенев И.С. Литературные и житейские воспоминания / Ред., коммент. и статьи А. Островского; вступ. статья А. Бескиной и Л. Цырлина. Л.: Изд-во писателей в Ленинграде, 1934. 344, [3] с.: ил.

Гоголь, Жуковский, Крылов, Лермонтов, Загоскин.

[О Гоголе: С. 116-130.]

Письмо из Петербурга. С. 125-126.

Тургенев И.С. Сочинения: В 12 т. Т. 11: Поэмы. Стихотворения. Воспоминания / Коммент. Б. Э<йхенбаума> Л.: Ленинградское отделение ГИХЛ, 1934. 679 с.

Гоголь. С. 432-441.

Коммент. С. 665-666.

Флит A. Н.В. Гоголь и другие (125 лет со дня рождения автора «Мертвых душ»): стихотворение // Смена. Л., 1934. 1 апреля. № 75. С. 3.

[С иллюстрациями Гливенко.]

Форш О. Ворон: роман. Л.: ГИХЛ, 1934. 148 с.

[А.А. Иванов и Гоголь.]

[Рец.: Десниикий В.А. «Ворон» О. Форш // Ленинградская правда. Л., 1934. 27 июля. № 174. С. 4; Книпович $E$. Символизм и современность // Художественная литература: критико-библиографический бюллетень. М., 1934. № 10. С. 8-11.]

Ходасевич В. Памяти Гоголя // Возрождение. Париж, 1934. 29 марта.

[Переиздано: Ходасевич В. Литературные статьи и воспоминания. Нью-Йорк, 1954. С. 83-91; Ходасевич В.Ф. Колеблемый треножник. М., 1991. С. 237-240; Трудный Путь. Зарубежная Россия и Гоголь / Сост., вступ. статья и коммент. М.Д. Филина. М.: Русскій Міръ, 2002. С. 69-76.]

Хорьков Н. Н.В. Гоголь (125 лет со дня рождения)// Труд. М., 1934. 30 марта. № 76(4024). C. 4 . 
Храпченко М.Б. Гоголь и дворянское общество (К 125 -летию со дня рождения Н.В. Гоголя) // Октябрь. М., 1934. № 5. С. 175-184.

Храпченко М. Н.В. Гоголь // Литературная газета. М., 1934. 30 марта. № 39(365). С. 2.

Храпченко М. Н.В. Гоголь (К 125-летию со дня рождения) // За коммунистическое просвещение. М., 1934. 30 марта. № 74(1545). С. 2.

Храпченко М.Б. Реализм Гоголя // Литературный критик. М., 1934. № 2. С. 13-32.

Хроника гоголевских дней в Ленинграде // Рабочий и театр. Л., 1934. № 10. С. 2-5.

[В институте русской литературы; оргкомитет писателей - Гоголю; Гоголевский сборник; новая «Женитьба»; академический Гоголь; записная книжка писателя; Гоголь в рисунке и живописи.]

Цейтлин А.Г. Литературные цитаты Ленина. М.; Л.: ГИХЛ [Гос. изд-во художественной литературы], 1934. 166 с.

[Образы Гоголя у В.И. Ленина: С. 57-68.]

Ценная находка // Красная газета (вечерн. вып.). Л., 1934. 10 июня. № 132. С. 2.

[В архиве бывшего Александринского театра обнаружен полный текст монтировки первого спектакля «Ревизора» Гоголя 25 апреля 1836 г. См.: Данилов С.С. «Ревизор» на сцене. 2-е изд., испр. и доп., с приложением монтировки первого спектакля / Гос. академия искусствознания. Л.: Гос. изд-во художественной литературы [ГИХЛ], 1934. 148 с.: ил.]

Шиф А. Великий русский писатель // Советская Украина. Киев, 1934. 30 марта. № 73. [О Гоголе.]

Школить, учить, пороть всерьез [Передовая статья] // За индустриализацию. М., 1934. 30 марта. № 76 (3742). С. 1.

[Почему популярен Гоголь. В чем его величие.]

Штакеншнейдер Е.А. Дневник и записки (1854-1886) / Ред., статья и коммент. И.Н. Розанова. М.; Л.: Academia, 1934. 582, [3] с. - (Русские мемуары, дневники, письма и материалы).

[C. 142 и 226: «Женитьба» и «Выбранные места из переписки с друзьями».]

Шуб А. Письмо Гоголю (Нечто вроде юбилейной статьи) // Рабочий край. Иваново-Вознесенск, 1934. 4 апреля. № 78. С. 4.

Энтелис Л. Гоголь в музыке // Литературный Ленинград. Л., 1934. 31 марта. № 15(37). С. 2.

Юбилейное издание «Мертвых душ» в изд. ГИХЛ // Экономическая жизнь. М., 1934. 30 марта. № 74(4655). С. 4.

Языков Н.М. Полное собрание стихотворений / Ред., вступ. статья и коммент. М.К. Азадовского. [Л.:] Academia, 1934. 927 с.

Из содерж.:

Н.В. Гоголю («Благословляю твой возврат...»): [стихотворение]. С. 583-585.

[Первоначально (под заглавием «Г***»): Москвитянин. 1842. Ч. 3. № 6. С. 229.]

Коммент. С. 834-836.

[О взаимоотношениях Гоголя и Н.М. Языкова.]

[Указ. имен.]

Яковлев М. Гоголь в Париже // Иллюстрированная жизнь. Париж, 1934. № 3.

Ясный П. Вечер, посвященный Н.В. Гоголю в Омском педагогическом институте 16 апреля 1934 г. // Рабочий путь. Омск, 1934. 20 апреля. № 81(5472). С. 4. 


\section{ПРОИЗ В Д ДЕНИЯ}

Мертвые души: поэма / Рис. А.А. Агина; примеч. Н.С. Ашукина. 2-е изд. М.. Художественная литература, 1935. 416 с. 40000 экз.

[В тексте 70 иллюстраций.]

Повести / Вступ. статья и примеч. Л.П. Гроссмана; ил. А.И. Кравченко. М.: Гос. изд-во художественной литературы, 1935. 325 с.: ил.

Загл. вступ. статьи: Гоголь-урбанист.

Содерж.: Нос; Невский проспект; Записки сумасшедшего; Портрет; Шинель.

Повести / Вступ. статья А. Ефремина. М.: Гос. изд-во художественной литературы, 1935. $255 \mathrm{c}$.

Загл. вступ. статьи: Социальный смысл петербургских повестей Гоголя. С. 3-19.

\section{ЛИТ Е РАТ У РА}

Адамович Г. На беседе о Гоголе // Последние новости. Париж, 1935. 28 февраля.

Амфитеатров А. [Фрагменты из кн. «Н.В. Гоголь. Человек, смешащий людей»] // Возрождение. Париж, 1935. 21, 22 июня. № 3700, 3701.

[Продолжение: 1936. 16 января. № 3879; 2 апреля. № 3956; 2 мая. № 3986; 1938. 21 января. № 4115; 1 апреля. № 4125.]

Анастасий (Грибановский), митрополит. Мысли о Гоголе // Митрополит Анастасий (Грибановский). Беседы с собственным сердцем. Иерусалим, 1935.

[Перепечатано: Великий Россиянин: сб. статей, посвященных памяти Н.В. Гоголя (1852-1952) / Комитет Российской колонии в Аргентине, Буэнос-Айрес, 1952. С. 7-8.]

Бескина А. Лицо и маска Михаила Зощенко // Литературный критик. М., 1935. № 2. C. 66-69.

Булгаков М.А., Коростин М.С. Необычайное происшествие, или Ревизор. М.: Цедрам, 1935.

[Вариант киносценария, издан соавторами в литографированном виде.]

Гиппиус В.В. Работа Гоголя над образами «Ревизора» // Рабочий и театр. Л., 1935. № 1. C. $20-22$.

Гиппиус B.B. Энергия негодования (К столетию начала работы Гоголя над Мертвыми душами) // Литературный Ленинград. М., 1935. № 57.

Глинский С.C. Психиатрический анализ Яновского. Для врачей. Введение (Конспективные патобиблиографические данные) / Архив библиотеки психиатра С.С. Глинского. Лодейное Поле, 1935 (На правах рукописи).

Данилов С.С. Гоголь: Указатель материалов к постановке произведений Н.В. Гоголя (К столетию первого представления «Ревизора» Н.В. Гоголя). Л.: Гос. академический театр драмы, $1935.40 \mathrm{c}$.

Диниес Л., Корнилов П. Герои Гоголя в изо-искусстве. Л., 1935. 114 с.: ил. - (Государственный Русский музей).

\section{Содерж.:}

Динцес Л. Дореволюционная иллюстрация. С. 3-36.

Корнилов П. Советская иллюстрация. С. 37-46.

[С приложением тридцати иллюстраций А.А. Агина, П.М. Боклевского, В.В. Пукирева, В.Г. Перова, К. Маковского, В.Е. Маковского, П.П. Соколова, М.М. Далькевича, Н. Алексеева.] 
[2-е изд., испр. М., 1937.]

Зайцев Б. Жизнь с Гоголем // Современные записки. Париж, 1935. № 59. С. 272-287. [Перепечатано: Литературная учеба. М., 1988. № 3 / Публ. Е.В. Воропаевой, примеч. В.А. Воропаева. С. 118-124; Трудный Путь. Зарубежная Россия и Гоголь / Сост., вступ. статья и коммент. М.Д. Филина. М.: Русскій Міръ, 2002. С. 98-118.

И.Б. Мертвые души // Литературный Ленинград. Л., 1935. 26 мая. № 24.

[Монтаж А. Шварца и П. Вейсбрема.]

Каринский В.Д. Н.В. Гоголь как православный христианин. Таллин: Русская книга, 1935. $22 \mathrm{c}$

Линии А.М. К вопросу о влиянии Гоголя на Островского (О поэтике «Записок замоскворецкого жителя») // Известия Ростовского-на-Дону пед. ин-та. Ростов-на-Дону, 1935. T. VI. C. 21-34.

[Отд. оттиск: Ростов-на-Дону, 1935.]

Литературное наследство. Т. 19-21: Языков. Тютчев. Лермонтов / Отв. ред. П.И. Лебедев-Полянский. М.: Журнально-газетное объединение, 1935. 714 с.

Из содерж.:

Некрасов А. Приписываемые Гоголю рисунки к «Ревизору»: С. 531-550.

Вейнберг А. Неизвестный портрет Гоголя работы Т.Г. Шевченко: С. 551-557.

Осипов H.E. Страшное у Гоголя и Достоевского // Жизнь и смерть: сб. памяти Н.Е. Осипова: В 2 т. / Под ред. А.Л. Бема, Ф.Н. Досужкова, Н.О. Лосского. Т. 1: Жизнь и посмертные труды. Прага; Берлин: Петрополис, 1935. С. 107-136.

[Доклад, прочитанный 26 февраля 1927 г. в Праге на семинаре по изучению Ф.М. Достоевского под руководством А.Л. Бема при Русском народном университете.]

Ремизов А.М. Без начала // Последние новости. Париж, 1935. 25 декабря.

Ходасевич В. По поводу «Ревизора» // Возрождение. Париж, 1935. 12 февраля.

[Перепечатано: Ходасевич В.Ф. Колеблемый треножник. М., 1991. С. 572-577.]

Шкловский В. «Портрет» и гоголевский реализм // Литературная газета. М., 1935. № 57.15 октября.

Эйхенбаум Б. «Женитьба» Гоголя в кино // Известия. М., 1935. 12 июня.

1936

\section{ПРОИЗВЕ ДЕНИЯ}

Мертвые души: поэма / Рис. А.А. Агина; примеч. Н.С. Ашукина. 3-е изд. [М.:] Гослитиздат, 1936. 430 с. 25000 экз.

[В тексте 70 иллюстраций.]

Мертвые души: поэма / Примеч. К.И. Халабаева, Б.М. Эйхенбаума и Н.С. Ашукина. М.: ГИХЛ, 1936. 451 с. 100000 экз.

Ревизор: [комедия в пяти действиях] / Ред., вступ. статья и примеч. В. Гиппиуса; рис. П.М. Боклевского. Л.: Гос. изд-во художественной литературы, 1936. 187 с.: ил. 10300 экз. Загл. вступ. статьи: «Ревизор» Гоголя. С. 7-36.

\section{Приложения:}

Отрывок из письма, писанного автором вскоре после первого представления «Ревизора» к одному литератору. С. $157-161$.

Две сцены, выключенные при первом издании как замедлявшие течение пьесы. С. 162-165.

Примеч. С. 167-179.

Библиографическая справка. С. 180-182. 
Боклевский П.М. Бюрократический катехизис.

[Илюстрации П.М. Боклевского к «Ревизору».]

Голлербах Э. П. Боклевский (Биографическая справка). С. 183-186.

Ревизор: комедия в пяти действиях. Сценическая история в иллюстративных материалах: Сто лет 1836-1936 / Текст С.С. Данилова; предисл. и вступ. статья акад. Н.С. Державина. М.; Л.: Гос. изд-во изобразительных искусств, 1936. 141 с.: 13 л. ил.: ил. (История театра в иллюстрациях и сценических документах / Под ред. П.Н. Шеффера; Ленинградский гос. академический театр драмы; Ленинградский театральный музей). Держсавин Н.С. Рождение «Ревизора».

Данилов С.С. Сценическая история «Ревизора» в иллюстративных материалах. - Первая постановка «Ревизора». - «Ревизор» в дореволюционном театре. - «Ревизор» на советской сцене. «Ревизор» за рубежом.

Собрание сочинений / Биографический очерк Н.С. Ашукина; вступ. статья А.В. Луначарского. 2-е изд. М.: ГИХЛ. 1936. 100000 экз.

[Рец.: Козьмин Б. // Литературное обозрение. М., 1936. № 13-14. С. 68-71; Дмитриев К. // Что читать. М., 1936. № 4. С. 62-63.

Собрание сочинений: В 3 т. / Под ред. Л.Б. Каменева и Л.И. Соловьева. 2-е изд. М.; Л.: ГИХЛ, 1936. - (Приложение к журналу «Красная нива»).

T. 1: Вечера на хуторе близ Диканьки. Миргород / Биографический очерк Н.С. Ашукина; вступ. статья Н.К. Пиксанова; примеч. Н.С. Ашукина. 449 с.

Т. 2: Повести и комедии / Вступ. статьи А.В. Ефремина и А.Г. Цейтлина; примеч. Н.С. Ашукина. $460 \mathrm{c}$.

Т. 3: Мертвые души / Вступ. статьи В.А. Десницкого и Вл. Данилова; примеч. Н.С. Ашукина. $375 \mathrm{c}$.

Собрание сочинений: В 3 т. / Под ред. В.И. Соловьева. 2-е изд. М.; Л., ГИХЛ, 1936. (Приложение к журналу «Красная нива») 85000 экз.

Т. 1: Вечера на хуторе близ Диканьки. Миргород / Биографический очерк Н.С. Ашукина; вступ. статья Н.К. Пиксанова; примеч. Н.С. Ашукина. 449 с.

Загл. вступ. статьи: Украинские повести Гоголя.

Т. 2: Повести и комедии / Вступ. статьи А.В. Ефремина и А.Г. Цейтлина; примеч. Н.С. Ашукина. $460 \mathrm{c.}$

Загл. вступ. статьи: Ефремин А.В. Социальный смысл петербургских повестей Гоголя.

Загл. вступ. статьи: Цейтлин А.Г. Гоголь-драматург.

Т. 3: Мертвые души / Вступ. статьи В.А. Десницкого и В.В. Данилова. Примеч. Н.С. Ашукина. $375 \mathrm{c}$.

Загл. вступ. статьи: Десниикий В.А. «Мертвые души» Гоголя как поэма дворянского возрождения. Загл. вступ. статьи: Данилов В.В. «Мертвые души» Н.В. Гоголя.

[В тексте 14 иллюстраций А.А. Агина.]

[3-е изд. М.; Л.: ГИХЛ, 1936. 85000 экз.]

\section{ЛИТ Е РАТ У РА}

Амфитеатров А. Отталкивающий магнит // Возрождение. Париж, 1936. 2 апреля, 2 мая; 11 июня.

Амфитеатров A. [Фрагменты из кн. «Н.В. Гоголь. Человек, смешащий людей»] // Возрождение. Париж, 1936. 16 января. № 3879; 2 апреля. № 3956; 2 мая. № 3986.

Бем А.Л. У истоков творчества Достоевского: Грибоедов, Пушкин, Гоголь, Толстой и Достоевский // О Достоевском: сб. статей под ред. А.Л. Бема. Т. 3. Прага: Петрополис, 1936. 215 c.

«Шинель» и «Бедные люди».

[Впервые: Записки Русского исторического общества в Праге. Прага, 1927. Кн. 1.]

«Нос» и «Двойник». Л.Толстой в оценке Достоевского

[Впервые: Научные труды Русского народного ун-та в Праге. 1929. Т. 2.] 
[Рец.: Бииилли П.М. // Современные записки. Париж, 1938. Кн. LXVII. C. 459-460; Ляикий Е. // Slavia. Прага, 1939. T. XVII. Вып. 1-2. С. 243-248; Словияов Р. [Калишевич Н.В.] // Последние новости. Париж, 1936. 30 октября. № 5669.]

Гиппиус B.B. Бесцензурный Гоголь // Правда. М., 1936. 7 октября. № 277.

Гиппиус B.В. Литературные взгляды Гоголя // Литературная учеба. Л., 1936. № 11. C. $52-73$

<Гоголь Н.В.> Н.В. Гоголь: Материалы к проектированию нового памятника / Всесоюзный комитет по делам искусств; сост. В.И. Покровский; ред. Г. Бандалин. М.; Л.: Искусство, 1936. 113, [3] с.

[Посчитав памятник Н.В. Гоголю скульптора Н. Андреева «не передающим образа великого сатирика», а трактующим его «как пессимиста и мистика», Всесоюзный комитет по делам искусств в 1936 г. объявил конкурс на новый памятник писателю. Исходя из этого комитет счел необходимым обеспечить всех участников конкурса документальными материалами, связанными с жизнью и творчеством Гоголя. Данное издание включает в себя комментированную иконографию Н.В. Гоголя, подборку высказываний о нем современников, библиографические данные и архитектурный проект будущей Арбатской площади - место сооружения памятника.] Машковцев Н.Г. Комментарий к иконографии Н.В. Гоголя. Список основного иллюстративного материала к биографии и сочинениям Н.В. Гоголя.

Эфрос А.М. Облик Н.В. Гоголя. Высказывания. Воспоминания.

Городеикий Б. Описание автографов Н.В. Гоголя в собрании Института литературы АН CCCP. M., 1936.

Гофман В.A. Язык и стиль повести Гоголя «Нос»// Русский язык в школе. М., 1936. № 5. C. $43-54$.

Данилов С.С. Гоголь и театр / Гос. научно-исследовательский институт искусствознания). Л.: Гослитиздат, 1936. 336 с.: ил.

Данилов С.С. Работа Гоголя-драматурга // Литературная учеба. Л., 1936. № 2. С. 100-117.

Данилов С.С. «Ревизор» на Александринской сцене (1836-1936). Л.: Гос. академический театр драмы, 1936. 42 с.: ил.

[К 100-летию со дня первой постановки.]

Десницкий В.А. На литературные темы. Кн. 2. Л.: Гослитиздат [Изд-во художественной литературы], 1936. 520 с.

Задачи изучения жизни и творчества Н.В. Гоголя.

О реализме Гоголя.

Егоров П. Работа над языком и стилем Мертвых душ Гоголя // Русский язык в школе. М., 1936. № 5. С. 55-66.

[Откл.: Жданов В. Клевета на классика // Правда. М., 1937. 4 марта.]

Лаврецкий А. Великий художник-реалист // Правда. М., 1936. 7 октября. № 277.

[О Гоголе.]

Литературный архив. Н.В. Гоголь: Материалы и исследования: В 2 т. / Академия наук СССР. Институт русской литературы; под ред. В.В. Гиппиуса. М.; Л.: Изд-во АН СССР, 1936.

Т. 1.502 с.: ил.

Содерж.:

От редакции. С. 1-2.

Неизданные и затерянные тексты Гоголя. Примеч. В. Гиппиуса, Н. Степанова С. Дурылина, М. Алексеева, Г. Виноградова. С. 3-45.

I. Первоначальный план «Арабесок». 
II. Предисловие к «Повести о том, как поссорился Иван Иванович с Иваном Никифоровичем».

III. Происшествия на Севере.

IV. Отрывки по истории Рима.

V. «Путешествие Александры Осиповны».

VI. Перечень авторов и книг.

VII. Заметки по фольклору.

Примеч. С. 21-45.

Письма Гоголя. Примеч. В. Гиппиуса, А. Пономарева, С. Дурылина, Г. Залкинда. С. 46-124.

Примеч. С. 90-124.

Письма к Гоголю (10). Примеч. А.Я. Максимовича, В.В. Гиппиуса, Н.Я. Морачевского. С. 125-150.

[П.В. Анненков (11 мая 1843 г.); В.И. Быков (21 августа 1851 г.); А.А. Иванов (февраль 1842 г.);

И.В. Капнист (23 июня 1849 г.); П.А. Плетнев (30 мая 1849 г.); С.В. Скалон (10 октября 1851 г.);

М.С. Скурдин (13 сентября 1851 г.); С.М. Соллогуб (17 мая 1849 г.); Ф.В.Чижов (1 августа 1844 г.).

Письма о Гоголе (28). Примеч. В.В. Гиппиуса, А.Г. Дементьева, Л.Н. Зубашовой-Перетц, К.В. Пигарева, И.Я. Айзенштока. С. 151-220.

[В.С. Аксакова (3) 1846-1847 гг; С.Т. Аксаков (7) 1842-1850 гг.; Н.Л. Баратынская (13 апреля 1843 г.); Е.Е. Бернардский (февраль 1846 г.); Е.В. Гоголь (около 25 декабря 1839 г.); М.Г. Карташевская (март 1852 г.); П.А. Плетнев (11) 1846-1847 гг; М.П. Погодин (9 марта 1852 г.); Н.Н. Шереметева (8 ноября 1942 г.); Н.М.Языков (2) 1845 г.]

Примеч. С. 189-220.

Неизданные и забытые статьи о Гоголе.

Одоевский В.Ф. <Две заметки о Гоголе>. Примеч. М. Брискмана. С. 223-225.

Примеч. С. 224-225.

Сенковский О.И. Рукописная редакция статьи о «Мертвых душах». Примеч. Н. Мордовченко. C. 226-248.

Григорьев А. Ф. Достоевский и школа сентиментального натурализма. Примеч. В.Л. Комаровича. C. 249-256.

Барбе д’Оревильи. Николай Гоголь. Примеч. М.П. Алексеева. С. 257-284.

Неизданные документы о Гоголе. С. 285-312.

Назаревский А.А. Из архива Головни. С. 313-358.

Дурылин С.Н. «Дело» об имуществе Гоголя. С. 359-374.

Библиография:

І. Добровольский Л.М., Лавров В.М. Библиографический указатель сочинений Гоголя и литературы о нем на русском языке за 1916-1934 гг. С. 375-473.

Указ. имен.

II. Гоголь в украинской литературе (УССР) 1917-1934. С. 474-498.

Указ. имен.

Значение сокращений. С. 499-500.

Т. 2.628 с.: ил.

Содерж.:

Десниџкий В.А. Задачи изучения жизни и творчества Гоголя. С. 1-105.

[Перепечатано: Десницкий В.A. Статьи и исследования. Л.: Художественная литература, 1979.

C. 58-164.]

Мордовченко Н.И. Гоголь и журналистика 1835-1836 гг. С. 106-150.

Гиппиус В.В. Проблематика и композиция Ревизора. С. 151-199.

Рулин П.И. «Женитьба». С. 200-241.

Алексеев М.П. Драма Гоголя из англо-саксонской истории. С. 242-284.

Виноградов В.В. Язык Гоголя. С. 286-376.

Красильников С.А. Источники собрания украинских песен Н.В. Гоголя. С. 377-406.

Машковиев Н. История портрета Гоголя. С. 407-422.

Данилов С.С. Гоголь в инсценировках. С. 423-471.

Берлинер Г.О. Чернышевский и Гоголь. С. 472-533.

Нечкина М.В. Гоголь у Ленина. С. 534-572. 
[Отд. изд.: Нечкина М.В. Гоголь у Ленина: с приложением сост. М.Н. Черневич «Указателя упоминаний Гоголя и героев Гоголя в сочинениях В.И. Ленина» / Академия наук СССР. М.; Л.: Издво АН СССР, 1936. 60 с.]

Черневич М.Н. Гоголь и гоголевские образы в сочинениях В.И. Ленина (указатель). С. 573-591. [Также в кн.: Нечкина. М.В. Гоголь у Ленина. М.; Л., АН СССР, 1936. С. 42-60.]

Динцеес Л.А. Комментарий к иллюстрациям. С. 592-596.

Указ. имен. Перечень иллюстраций. С. 623-625.

Значение сокращений. С. 626-627.

Маяковский В.В. Выступление на диспуте о постановке «Ревизора» в Гос. театре им. Вс. Мейерхольда 3 января 1927 года // Советский театр. М., 1936. № 8.

[Стенограмма диспута. Стенографическая запись выступления В.В. Маяковским не правлена. В диспуте приняли участие А.В. Луначарский, В.Э. Мейерхольд, писатели А. Белый, С.М. Третьяков, И.А. Аксенов, режиссер Н.О. Волконский, критики И.С. Гроссман-Рощин, М.Ю. Левидов, Р.А. Пельше, А.Л. Слонимский и др. В отчете о диспуте (Правда. М., 1927. 9 января. № 7. C. 7), в частности сообщалось: «Диспут, закончившийся в 2 часа ночи, прошел в страстном тоне, причем слушатели горячо реагировали на каждое выступление».]

[Перепечатано: Маяковский В.В. Полное собрание сочинений: В 13 т. Т. 12: Статьи, заметки и выступления. Ноябрь 1917-1930 / Академия наук СССР; Институт мировой литературы им. А.М. Горького. М.: Гос. изд-во художественной литературы, 1959. С. 306-311.]

Нечкина М.В. Гоголь у Ленина: с приложением сост. М.Н. Черневич «Указателя упоминаний Гоголя и героев Гоголя в сочинениях В.И. Ленина» / Академия наук СССР. М.; Л.: Изд-во АН СССР, 1936. 60 с.

Никитин Н.И. Искусство характеристики // Литературная учеба. Л., 1936. № 6. С. $28-55$. [Художественные образы в «Мертвых душах» Гоголя.]

О «Ревизоре»: сб. статей к постановке комедии Н.В. Гоголя «Ревизор». Л.: Театр юных зрителей, 1936. 173 с.: ил.

Брянцев А.А. К постановке «Ревизора».

Макарьев Л.Ф. На пути к «Ревизору».

Предтеченский А.В. Эпоха Николая I.

Гиппиус B.B. Николай Васильевич Гоголь.

Десниикий В.А. О реализме «Ревизора».

Данилов С.С. Драматургия Гоголя.

Приложение:

Главнейшие даты сценической истории «Ревизора» за сто лет.

Предтеченский А.В. Эпоха Николая I. С. 37-74.

Рулин П. Гоголь в театре // Театр и драматургия. М., 1936. № 9.

Симов B. Эскизы к Мертвым душам: губернатор, Петрушка, и Собакевич // Театр и драматургия. М., 1936. № 9. С. 551-552.

Тамарченко Д. Литература и эстетика. Л.: Гос. изд-во художественной литературы, 1936. 235 c.

Мировоззрение и метод Гоголя. С. 202-233.

Ходаков Г. Был ли Гоголь в Ржеве // Ржевская правда. Ржев, 1936. 18, 20 октября. № 243,244 .

Храпченко М.Б. Н.В. Гоголь. М.: Художественная литература, 1936. 212 с.

[Рец.: Иванов И. // Литературное обозрение. М., 1936. № 8. С. 36-41; Македонов А. // Литературный критик. М., 1936. № 11. С. 181-193; Фридлендер Г. // Литературный критик. М., 1936. № 5. С. 40-44.]

Храпченко М. Юмор и сатира в творчестве Гоголя // Литературная учеба. Л., 1936. № 1. C. 71-91. 
Черняк Я.3. Письмо Белинского к Гоголю // Красная новь. М., 1936. № 7. С. 233-234.

1937

\section{ПРОИЗВЕ ДЕНИЯ}

Вечера на хуторе близ Диканьки. Миргород / Биографический очерк Н.С. Ашукина; примеч. Б.Х. Черняка. Минск: ГИХЛ, 1937. 469 с. - (Дешевая библиотека ОГИЗ). 75000 экз.

Избранные произведения / Ред., биографическая статья и примеч. В. Гиппиуса. М.; Л.: Изд-во детской литературы. 1937. 776 с.: 11 л.: ил. 20000 экз.

Загл. биографической статьи: Жизнь Гоголя. С. 2-71.

Содерж.: Вечера на хуторе близ Диканьки; Миргород; Записки сумасшедшего; Нос; Коляска; Шинель; Ревизор; Женитьба; Игроки; Мертвые души (Т. 1-2).

Примеч. С. $727-754$.

Макогоненко Г., Буторин Д. Объяснения непонятных слов и выражений. С. 755-775.

[В тексте 27 иллюстраций А.А. Агина, рисунок В.Г. Перова: Погребение Гоголя героями его произведений, рисунок Э.А. Дмитриева-Мамонова: Гоголь читает Мертвые души и рисунок Гоголя - обложка к Мертвым душам.]

[Рец.: Тагер Е. // Детская литература. М., 1937. № 18. С. 20-23; Роскин А. // Литературная газета. М., 1937. № 47.]

Мертвые души: поэма. Т. 1-2 / Рис. А.А. Агина. М.; Л.: Academia, 1937. 508 с.: ил. 20300 экз.

[В тексте 73 иллюстрации.]

[Рец.: Кауфман Р.С. // Искусство. М., 1939. № 1. С. 83-101.]

Мертвые души: поэма: В 2 ч. Хабаровск: Дальгиз [Дальневосточное гос. изд-во], 1937. 471 с. 15000 экз.

Петербургские повести / Подгот. текста Б.М. Эйхенбаума; худож. Н. Альтман. М.; Л.: Academia, 1937. $141 \mathrm{c}$.

Полное собрание сочинений: [В 14 т.] / Академия наук СССР. Институт русской литературы (Пушкинский Дом); гл. ред. Н.Л. Мещеряков. [Л.]: Изд-во АН СССР, 1937-1952.

Т. 2: Миргород / Тексты и коммент. подгот. И.Я. Айзеншток, В.В. Гиппиус, В.П. Петров, Н.Л. Степанов, Б.М. Эйхенбаум; ред. тома В.В. Гиппиус. [Л.]: Изд-во АН СССР, 1937. 764 с.: ил. 15175 экз.

Содерж.:

Миргород: повести, служащие продолжением Вечеров на хуторе близ Диканьки. Ч. 1-2. С. 5-276.

Другие редакции. С. 277-456.

Варианты. С. 455-677.

Коммент. С. 679-760.

Перечень иллюстраций. С. 761.

Собрание сочинений / Биографический очерк Н.С. Ашукина; вступ. статья А.В. Луначарского. 3-е изд. М.: ГИХЛ, 1937. 100000 экз.

[Рец.: Г.Ф. // Новый мир. М., 1937. № 6. С. 269-270.]

Собрание сочинений: В 6 т. / Под ред. Н.С. Ашукина, В.Ф. Переверзева и М.Б. Храпченко. М.: Гос. изд-во художественной литературы [ГИХЛ], 1937-1941.

Т. 1: Вечера на хуторе близ Диканьки: повести, изданные пасичником Рудым Паньком. Юношеские опыты / Ред. В.Ф. Переверзева; вступ. статья М.Б. Храпченко. М.: ГИХЛ, 1937. 296 с. 50000 экз.

Загл. вступ. статьи: Жизнь и творческая деятельность Гоголя. C. V-LXIII.

Юношеские опыты: 
Непогода. С. 249.

Италия. С. 250-251.

Ганц Кюхельгартен. С. 252-293.

Примеч. С. 294.

Т. 2: Миргород. Незаконченные произведения и отрывки. М.: ГИХЛ, 1937. 435 с.

\section{Приложения:}

Тарас Бульба (первая редакция).

Предисловие к «Повести о том, как поссорился Иван Иванович с Иваном Никифоровичем».

Т. 3: Повести / Ред. Н.С. Ашукина. М.: ГИХЛ, 1937. 325 с.

Содерж.: Невский проспект; Записки сумасшедшего; Нос; Портрет; Шинель; Коляска; Рим; Отрывки.

\section{Приложение:}

Портрет (первая редакция). С. 278-321.

Примеч. С. 323-324.

Т. 4: Комедии. Драматические отрывки и отдельные сцены / Ред. Н.С. Ашукина, В.Ф. Переверзева. М.: ГИХЛ, 1937. 503 с.

Содерж.: Ревизор; Театральный разъезд после представления новой комедии; Развязка «Ревизора»; Дополнение к Развязке «Ревизора»; Женитьба; Игроки; Утро делового человека; Тяжба; Лакейская; Отрывок; Альфред (начало трагедии из английской истории); Отрывок из утраченной драмы; Заметки и наброски для драмы из украинской истории.

\section{Приложения:}

Рукописный текст «Ревизора» во второй редакции. С. 355-463.

Отрывок из письма, писанного автором вскоре после первого представления «Ревизора» к одному литератору. С. 464-470.

Предуведомление для тех, которые пожелали бы сыграть как следует «Ревизора». С. 471-481. Примеч. С. 499-502.

Т. 5: Мертвые души. Т. 1-2 / Под ред. Н.С. Ашукина, В.Ф. Переверзева и М.Б. Храпченко. М.: ГИХЛ, 1937. $575 \mathrm{c.}$

Том первый. С. 5-291.

Том второй. С. 293-437.

Приложение:

Повесть о капитане Копейкине в разрешенной цензурой редакции. С. 441-445.

Окончание IX главы в переделанном виде. 445-452.

Предисловие ко второму изданию «Мертвых душ». С. 452-455.

Второй том «Мертвых душ» в одной из первоначальных реакций. С. 455-572.

Примеч. С. 573-574.

Сочинения: В 3 т. / Худож. Кукрыниксы. М.; Л.: Изд-во детской литературы, 1937-1938. 20300 экз.

Т. 1. Вечера на хуторе близ Диканьки; Миргород; Повести. 467 с.: 26 л. ил.: ил.

[Повести: Нос; Шинель; Коляска.]

Т. 2. Драматические произведения. 175 с.: 15 л. ил.: ил.

[Ревизор; Женитьба.]

Т. 3. Мертвые души: поэма [Т. 1-2.] 319 с.: 27 л. ил: ил.

[Рец.: Кауфман Р.С. // Искусство. М., 1939. № 1. С. 83-101.] 


\section{Л И Т Е РАТ У РА}

Абрамович Г.Л. Пушкин и Гоголь // А.С. Пушкин. 1837-1937: [сб. статей]. М.: Учпедгиз, 1937. С. 5-21.

Айзеншток И. Герцен - литературный критик // Литературный критик. М., 1937. № 5. C. $18-43$.

[А.И. Герцен и Гоголь.]

Амфитеатров А. Комедия ошибок // Земля Колумба. Нью-Йорк, [Сан-Франциско, Лос-Анжелес, Чикаго, Буэнос-Айрес, Рио-де-Жанейро], 1937. Кн. 2.

[О «Ревизоре» Гоголя.]

Варшавскиий Л.Р. Русская карикатура 40-50-х гг. ХІХ в. Без м. изд. ОГИЗ - ИЗОГИЗ, 1937. 147 c.

[А.А. Агин - иллюстратор «Мертвых душ» Гоголя. С. 35-42.]

Вейдле В. Умирание искусства. Размышления о судьбе литературного и художественного творчества. Париж: Издание $\mathrm{P}<$ усского $>\mathrm{C}<$ туденческого $>\mathrm{X}<$ ристианского $>$ Движения и газеты «Путь Жизни», 1937.

[Переиздано: СПб.: Аксиома, Мифрил, 1996. 336 с. - (Классика искусствознания).]

[О Гоголе: С. 92-94.]

Гериен А.И. Избранные сочинения. М.: Гослитиздат, 1937. 526 с.

О развитии революционных идей в России. С. 389-416.

Гиппиус В.В. Великий обличитель // Известия. М., 1937. № 55. 4 марта.

[О Гоголе.]

$<$ Гоголь Н.В.> Н.В. Гоголь. Мертвые души: драматическая композиция М.А. Булгакова. М.: Издание музея Московского художественного академического театра им. М. Горького, 1937. 34 с.: ил.

Сахновский В.Г. О спектакле «Мертвые души».

[О постановке поэмы Гоголя на сцене МХАТ в 1932 г.]

[В приложении шестнадцать фотографий актеров-исполнителей и отдельных сцен.]

Горький М. О литературе: статьи и речи 1928-1936 / Ред. Н.Ф. Бельчиков. 3-е изд., доп. М.: Советский писатель, 1937. 515 с.

[Указ. имен.]

Дерман А.Б. Михаил Семенович Щепкин (1788-1863). М.; Л.: Искусство, 1937. 93, [2] с.: ил. - (Великие мастера искусства. Театр).

[M.С. Щепкин и Гоголь.]

Десницкий В.А. Великий русский художник-реалист // Известия. М., 1937. 3 марта. № 54. [О Гоголе.]

Диниес Л., Корнилов П. Герои Гоголя в изобразительном искусстве. 2-е изд., испр. Л.: Гос. русский музей, 1937. 114 с.: ил.

Динцес Л.А. Дореволюционная иллюстрация. С. 3-36.

Корнилов П.Е. Советская иллюстрация. С. 37-46.

Жестокая потеря // Правда. М., 1937. № 62.

Заславский Д. Горький смех от любви // Правда. М., 1937. 4 марта. № 62.

[О Гоголе.]

Лозинский Г.Л. Пушкин и Гоголь («Евгений Онегин» и «Мертвые души») // Пушкин. Однодневная газета. Париж, 1937. Февраль.

[Перепечатано: Трудный Путь. Зарубежная Россия и Гоголь / Сост., вступ. статья и коммент. М.Д. Филина. М.: Русскій Мірь, 2002. С. 134-138.] 
Луначарский А.В. Классики русской литературы / Ред. Н.Ф. Бельчиков. М.: Гослитиздат, 1937. 504 с.: ил.

Н.В. Гоголь. С. 189-196.

[Первоначально: Красная нива. М., 1924. № 12. С. 284-286.]

Мандельштам Ю. В Париже с Гоголем // Возрождение. Париж, 1937. 24 декабря.

Мериме П. Избранные произведения. М., Л.: Гослитиздат, 1930. 191 с.

Николай Гоголь.

Огарев Н.П. Стихотворения и поэмы: В 2 т. Т. І. Л.: Советский писатель, 1937. 428 с. (Библиотека поэта).

Предисловие к сборнику «Русская потаенная литература». С. 343-345.

Переверзев В.Ф. У истоков русского реального романа. М.: Гослитиздат, 1937. 144, [3] с. [Гоголь и В.Т. Нарежный].

[2-е изд. под названием: У истоков русского реалистического романа. М.: Художественная литература, 1965. См. также: Переверзев В.Ф. У истоков русского реализма: [сб.] М.: Современник, 1989. $752 \mathrm{c}$.

Рагозин А.С. Мертвые души (К 95-летию со дня выхода первого тома) // Литературная газета. М., 1937. 30 мая. № 29.

Розенивейг Б. Н.В. Гоголь: К 85-летию со дня смерти // Комсомольская правда. М., 1937. 4 марта. № 51.

Сахновский В.Г. Работа режиссера. М.; Л.: Искусство, 1937. 287с.: ил.

Работа над спектаклем «Мертвые души» (апрель 1930 г. - декабрь 1932 г.). С. 201-277.

1842 г. Вышли «Мертвые души» // Литературная газета. М., 1937. 30 мая. № 29.

Флоровский Г., протоиерей. Пути русского богословия. Париж, 1937.

Гоголь: С. 260-270.

[Перепечатано: О России и русской философской культуре. Философы русского послеоктябрьского зарубежья. М.: Наука, 1990. С. 300-312; Флоровский Г., протоиерей. Пути русского богословия. Вильнюс, 1991; Флоровский $Г$., протоиерей. Проблема христианской культуры у Гоголя (Из книги «Пути русского богословия») // Трудный Путь. Зарубежная Россия и Гоголь / Сост., вступ. статья и коммент. М.Д. Филина. М.: Русскій Міръ, 2002. С. 119-133.]

Храпченко М.Б. Великий реалист // Литературная газета. М., 1937. 5 марта. № 12.

[О Гоголе.]

Чапленко В.К. Фольклор в творчестве Гоголя // Литературная учеба. Л., 1937. № 12. C. $73-89$.

Шелегов В. Синтаксис «Мертвых душ» Гоголя // Литературная учеба. Л., 1937. № 7. C. $64-78$.

Шкловский В.Б. [Заметка о рисунке Гоголя - обложка к изданию «Мертвых душ» 1842 г.] // Огонек. М., 1937. № 13. С. 17. 


\section{ПРОИЗ В Е ДЕНИЯ}

Мертвые души: поэма. Минск: Гизбел, Сектор художественной литературы, 1938. 507 с. 10185 экз.

Полное собрание сочинений: [В 14 т.] / Академия наук СССР. Институт русской литературы (Пушкинский Дом); гл. ред. Н.Л. Мещеряков. [Л.]: Изд-во АН СССР, 1937-1952.

Т. 3: Повести / Тексты и коммент. подгот. И.Я. Айзеншток, В.Л. Комарович, Н.И. Мордовченко, Н.Л. Степанов, Б.М. Энгельгардт; ред. тома В.Л. Комарович. [Л.]: Изд-во АН СССР, 1938. 728 с.: ил. 15175 экз.

\section{Содерж.:}

Невский проспект. С. 7-46.

Hoc. C. $47-75$.

Портрет. С. $77-137$.

Шинель. С. 139-174.

Коляска. С. 175-189.

Записки сумасшедшего. С. 191-214.

Рим: отрывок. С. 215-259.

Отрывки:

Две главы из малороссийской повести «Страшный кабан». С. 263-276.

Гетьман. С. 277-323.

Ночи на вилле. С. 324-326.

Мелкие отрывки:

Страшная рука. С. 329.

$<$ Фонарь умирал.> С. 329-331.

<Дождь был продолжительный.> С. 331-333.

Рудокопов. С. 333.

$<$ Семен Семенович Батюшек.> С. 333-334.

$<$ Девицы Чабловы.> С. 335.

Другие редакции. С. 337-476.

Варианты. С. 477-632.

Коммент. С. 633-724.

Перечень иллюстраций. С. 725.

\section{ЛИТ Е РАТ У РА}

Абрамович Г.Л. О гуманизме Гоголя // Литература в школе. М., 1938. № 1. С. 58-62.

Альтман И. «Ревизор» // Литературный критик. М., 1938. № 4. С. 67-68.

[О постановке комедии Гоголя «Ревизор» в 1938 г. на сцене Московского академического Малого театра.]

Амфитеатров А. [Фрагменты из кн. «Н.В. Гоголь. Человек, смешащий людей»] // Возрождение. Париж, 1938. 21 января. № 4115; 1 апреля. № 4125.

Богословский Н. Литературные взгляды Тургенева // Красная новь. М., 1938. № 11. C. 249-268.

[В частности, отношение И.С. Тургенева к творчеству Гоголя.]

Великий русский писатель // Литературный критик. М., 1938. № 4. С. 13-15.

[О Гоголе.]

Вересаев B.B. Гоголь в жизни. Систематический свод подлинных свидетельств современников. М.; Л.: Academia, 1938. $531 \mathrm{c.}$ 
Гиппиус B.B. Об историко-литературном значении Гоголя // Литературный критик. М., 1938. № 4. С. $16-40$.

$<$ Гоголь Н.В.> Письма Гоголя Аксакову от 6 марта 1847 и 1852 г. // Всесоюзная библиотека имени В.И. Ленина. Записки Отдела рукописей. Вып. 1. М.: Соцэкгиз, 1938.

Голубов В. «Ах, какой пассаж...»// Театр. М., 1938. № 7. С. 90-94.

[Актер И. Ильинский в роли Хлестакова. К постановке «Ревизора» в Московском Малом театре.]

Городеикий Б.П. Записная книжка Гоголя (Новые строки Гоголя) // Ученые записки Ленинградского пед. ин-та им. М.Н. Покровского. Л., 1938. Вып. 1. С. 61-71.

Городеикий Б.П. Описание автографов Н.В. Гоголя в собрании Института литературы АН СССР // Литературный архив: Материалы по истории литературы и общественного движения. Т. І. М.; Л.: Академия наук СССР, 1938. С. 432-474. - (Институт русской литературы).

Данилов С.С. «Ревизор» на сцене / Предисл. Н.В. Петрова. Харьков: Харьковский гос. театр русской драмы, 1938. 144 с.: ил. - (Библиотека Харьковского гос. театра русской драмы; Вып. 2).

Данилов С. Щепкин и Гоголь // Искусство и жизнь. Л., 1938. № 8. С. 6-9.

Жданов В.В. Героическая эпопея «Тарас Бульба» // Литературный критик. М., 1938. № 4. C. 41-53.

Железнов Н. Рассказы Щепкина <записанные его современниками> // Театр. 1938. № 8. C. $46-50$.

Загорский М. Щепкин в оценке современной ему критики [C приложением выдержек из рецензий за 1828-1862 гг.] // Театр. М., 1938. № 19.

Замошкин Н.И. Неузнанный Гоголь // Знамя. Л., 1938. № 4. С. 234-257.

[Об историзме писателя.]

Записки актера Щепкина (1788-1938) / Предисл., прим. и статья А.Б. Дермана. М., 1938. $224 \mathrm{c}$.

Ильин В.Н. Аскеза и творчество // Вестник РСХД [Русское студенческое христианское движение]. Париж, 1938. № 5.

Инсценировки (по Гоголю и Чехову). М.: Искусство, 1938. 79 с.

Ипполитов Н. Новые материалы о Пушкине, Гоголе // Литературная газета. М., 1938. 10 июня.

Лавреикий А. Гоголь в оценке Белинского и Чернышевского // Литературный критик. М., 1938. № 4. C. 89-113.

Леушева С.И. Мертвые души // Литература в школе. М., 1938. № 4. С. 38-53.

Материалы в помощь учителю: Литература. [М.:] НКП [Народный комитет просвещения] РСФСР, 1938. 78 с. - (Управление средней школы НКП РСФСР).

Из содерж.:

Денисенко 3.К. Чтение произведений Н.В. Гоголя в VI классе.

Машинский С.О. Гоголь и народная историко-поэтическая традиция // Литературная учеба. Л., 1938. № 3. С. 26-54. 
Письма матерям... // Пионер. М., 1938. № 3. С. 31-36.

[Письма Гоголя.]

$<$ Толстой А.П.> [Письмо графа А.П. Толстого к С.П. Апраксиной и переписка о Гоголе] // Всесоюзная библиотека имени В.И. Ленина. Записки Отдела рукописей. Вып. 1 / Под общ. ред. Е.Ф. Розмирович. М.: Соцэкгиз, 1938. С. 32-35.

«Ревизор» Н.В. Гоголя на сцене Малого театра: [сб. материалов]. М.: Музей Малого театра, 1938. 48 с.: ил.

Кудрявчикова В. О «Ревизоре» Гоголя.

Маслих $B$. «Ревизор» на сцене Малого театра.

Волков Л.А. Режиссер о спектакле.

Юон К. Ф. Художник о спектакле.

Актеры о работе над ролью.

[Высказывания Н.К. Яковлева (Городничий), В.Н. Пашенной (Анна Андреевна), В.Э. Мейера (Хлестаков), М.М. Климова (Земляника), А.И. Ржанова (Ляпкин-Тяпкин), Н.А. Светловидова (Бобчинский), П.А. Оленева (Добчинский), Н.Ф. Костромского (Осип), Г.И. Коврова (Почтмейстер).]

Ремизов А.М. Рисунки писателей // Временник Общества друзей русской книги. Париж, 1938. Вып. 4.

[К статье приложены воспроизведения рисунков Гоголя, А.С. Пушкина, М.Ю. Лермонтова, Ф.М. Достоевского.]

Розанов И.Н. Некрасов о Пушкине и Гоголе // Литературная учеба. Л., 1938. № 1. C. $68-79$.

Словиов Г. [Калишевич Н.В.] «Мертвые души в Художественном театре // Последние новости. Париж, 1938. 31 мая. № 6274.

Чижевский Д.И. О «Шинели» Гоголя // Современные Записки. Париж, 1938. № 67. C. $172-195$.

[Перепечатано: Философская и социологическая мысль. М., 1994. № 5/6. С. 75-97; Дружба народов. М., 1997. № 1 / Предисл., примеч. и подгот. текста М. Васильевой. С. 199-218; загл. предисл.: «Шинель» и пересечение параллелей. С. 199-205.

Шкловский В. Заметки о Гоголе // Знамя. Л., 1938. Кн. 7-8. С. 305-310.

Шкловский В. Иллюстрации Кукрыниксы к «Мертвым душам» // Детская литература. М., 1938. № 4. С. 30-36.

[В тексте 10 иллюстраций.]

Шкловский В.Б. О Хлестакове, Чичикове, о Мертвых душах и о песне // Литературный критик. М., 1938. № 4. С. 54-66.

1939

\section{ПРОИЗ В ЕДЕНИЯ}

Мертвые души: поэма / Рис. А.А. Агина. М.: ГИХЛ, 1939. 476 с.: ил. - (Школьная библиотека) 25000 экз.

[В тексте 13 иллюстраций.]

Шинель. Ростов-на-Дону: Ростиздат, 1939. 10000 экз.

[Единственное советское издание Гоголя в миниатюрном формате.]

\section{Л И Т Е РАТ У РА}

A.А. Н.В. Гоголь // Коммунист. М., 1939. 30 марта. № 73.

[К 130-летию со дня рождения.] 
Айзеншток И. Гоголь и фольклор // Літературна критика. Киев, 1939. № 7.

Александров Р. Салтыков-Щедрин и Гоголь // Звезда. Л., 1939. № 5-6. С. 269-275.

Арго A.M. Сатирические очерки из истории русской литературы: В 4 ч. М.: Гослитиздат, 1939. 144 с.: ил.

Ашукин Н. Первое издание собрания сочинений Н.В. Гоголя // Книга и пролетарская революция. М., 1939. № 3. С. 154-155.

Беркин С. Великий мастер слова (К 130-летию со дня рождения Н.В. Гоголя) // Учительская газета. М., 1939. 1 апреля. № 44.

Вальбе Б.Е. Наш Гоголь (К 130-летию со дня рождения) // Известия. М., 1939. 30 марта. № 75. C. 3 .

Васильев B. «Ни в городе Богдан, ни в селе Селифан» // Комсомольская правда. М., 1939. 1 апреля. № 74.

[Иллюстрация к речи И.В. Сталина на предвыборном собрании избирателей Сталинского избирательного округа г. Москвы.]

Веселовский А.Н. Избранные статьи / Институт литературы Академии наук СССР; под общ. ред. М.П. Алексеева, В.А. Десницкого, В.М. Жирмунского и А.А. Смирнова; вступ. статья В.М. Жирмунского; коммент. М.П. Алексеева. Л.: Гослитиздат, 1939. XXIV, $572 \mathrm{c}$.

Из содерж.:

Данте. С. 140-152.

[Гоголь и Данте.]

Воложенин А. Великий художник-реалист. К 130-летию со дня рождения Н.В. Гоголя // Гудок. М., 1939. № 73.30 марта.

Гебель В.А. Н.В. Гоголь // Что читать. М., 1939. № 3. С. 36-38.

Гиппиус В.В. Н.В. Гоголь // Краснофлотец: двухнедельный литературно-художественный журнал. Л., 1939. № 6. С. 22-24.

Гиппиус В.В. Н.В. Гоголь // Октябрь. М., 1939. № 2. С. 178-195.

$<$ Гоголь Н.В.> Н.В. Гоголь. 1809-1852: Краткий указатель литературы / Наркомпрос РСФСР; Научно-исследовательский институт библиотековедения и рекомендательной библиографии; сост. Е.С. Смирнова-Чикина. М., 1939. 12 с.

Городинский В. Поэт жизни действительной // Комсомольская правда. М., 1939. 1 апреля. № 74.

[О Гоголе.]

Горький А.М. История русской литературы / Ред. текста И.П. Ладыжников, М.М. Юнович; примеч. М.М. Юнович. М.: Гослитиздат [Изд-во художественной литературы], 1939. XII, 340 с.: ил. - (Архив А.М. Горького / Академия наук СССР. Институт мировой литературы им. А.М. Горького. Т. 1).

[Указ. имен.]

Еголин А.М. Н.В. Гоголь (К 130-летию со дня рождения) // Новый мир. М., 1939. № 4. C. 200-212.

Жданов В. Великий художник слова (К 130-летию со дня рождения Н.В. Гоголя) // Правда. М., 1939. 30 марта. № 88. 
Зайщев Б. Москва. Париж: Русские записки, 1939. 302 с.

Из содерж.:

Гоголь на Пречистенском.

[Впервые: Возрождение. Париж, 1931. 29 марта. № 2126. С. 3-4.]

[Переиздано: Зайщев Б. Москва. 2-е изд. Мюнхен, 1960; 3-е изд. Мюнхен, 1973; Литературная учеба. М., 1988. № 3 / Публ. и вступ. статья Е.В. Воропаевой, примеч. В.А. Воропаева. С. 115117; загл. вступ. статьи: Борис Зайцев о Гоголе. С. 111-115.]

Заславский Д.И. Чудная власть Гоголя // Литературная газета. М., 1939. 30 марта. № 18.

И. К. Н.В. Гоголь (130 лет со дня рождения) // Водный транспорт. М., 1939. 30 марта. № 44.

Ивановский Н. Н.В. Гоголь. К 130-летию со дня рождения // Индустрия. М., 1939. 30 марта. № 73.

Иващенко А. Новый документ о Гоголе // Литературная газета. М., 1939. № 38.

[О намерении Гоголя побывать в Симбирске весной 1850 г. Письмо, полученное женой А.М. Языкова, где сообщалось, что Гоголь едет в Симбирск.]

Израилевич Л. К вопросу о влиянии Гофмана на Гоголя // Ученые записки Ленинградского ун-та. № 33. Серия филологических наук. Вып. 2. Л.: Изд-во ЛГУ, 1939. С. 148-154.

Кауфман Р.С. Агин и Кукрыниксы. Два издания Мертвых душ Н.В. Гоголя // Искусство. М., 1939. № 1. С. 83-101.

[В тексте 20 иллюстраций.]

Кварелашвили Г. Великий писатель-реалист (К 130-летию со дня рождения Гоголя) // Заря востока. Тифлис, 1939. 30 марта. № 73.

Келчевский М. Великий реалист // Коммунист. М., 1939. 30 марта. № 73.

[О Гоголе.]

Кубиков И.Н. Н.В. Гоголь (К 130-летию со дня рождения) // Районная и фабрично-заводская печать. М., 1939. № 7. С. 40-42.

Лейтес А. Н.В. Гоголь (К 130-летию со дня рождения) // Труд. М., 1939. 30 марта. № 72.

Леонтьева 3. «Мертвые души»: методическая разработка для VIII класса // В помощь учителю. Киров, 1939. С. 55-66.

Машковиев Н.Г. Проблема памятника Гоголю // Искусство. М., 1939. № 6. С. 171-183.

Мордовченко Н.И. Гоголь в Петербургском университете (Неизданные письма Гоголя и материалы о нем) // Ученые записки Ленинградского гос. ун-та. Серия филологических наук. Вып. 3. Л., 1939. С. 355-359.

Мордовченко Н.И. Гоголь в работе над «Портретом» // Ученые записки Ленинградского гос. ун-та. Серия филологических наук. Л., 1939. Вып. 4. С. 97-124.

Московский художественный театр. 1898-1938: Библиографический указатель / Bceроссийское театральное общество; сост. А.А. Аганбекян; ред. и предисл. С.Н. Дурылина. М.; Л., 1939. 108 с.

[О постановках произведений Гоголя на сцене МХАТ: С. 49-51.]

Мочульский К.В. Гоголь // Мочульский К.В. Великие русские писатели ХІХ в. Париж: Дом книги, 1939. С. 77-100. - (Книги о России для молодежи; Кн. 1).

[Рец.: Пильский П.М. Душа русской литературы // Сегодня. Рига, 1939. № 231.] 
[Переиздано: Мочульский К.В. Великие русские писатели XIX в. / Предисл. Л. Магаротто. СПб.: Алетейя, 2000. С. 81-104.]

Мышковская Л.М. Язык и стиль «Мертвых душ» // Литературная учеба. Л., 1939. № 2. C. 86-99.

На родине великого писателя // Комсомольская правда, М., 1939. 1 апреля. № 74.

[Об иллюстрациях к «Мертвым душам» в Доме-музее Гоголя в Сорочинцах.]

Наумов Н. Н.В. Гоголь. К 130-летию со дня рождения // Легкая индустрия. М., 1939. 30 марта. № 73 .

Нейман Б.В. Н.В. Гоголь (1809-1939) // Московский большевик. М., 1939. 30 марта. № 24 .

Никитин Н. Искусство характеристики (Построение образа-персонажа в «Мертвых душах») // Литературная учеба. Л., 1939. № 6. С. 28-55.

Семенов-Тян-Шанский В.П. Мысли Н.В. Гоголя о географии: К 130-летию со дня рождения // Известия гос. географического общества. 1939. Т. 71. Вып. 6. С. 869-873.

Серапионова 3. Гофмановские мотивы в «Петербургских повестях» Гоголя // Литературная учеба. Л., 1939. № 8. С. 78-92.

Смелянинов С. Цензурные мытарства Мертвых душ // Днепропетровская правда. Днепропетровск, 1939. 30 марта. № 73.

Смирнова-Чикина E.C. Н.В. Гоголь. 1809-1852: Краткий указатель литературы / Наркомпрос РСФСР. Научно-исследовательский институт библиотековедения и рекомендательной библиографии. М., 1939. 12 с.

Теребинский В.И. О болезни Гоголя // Русский врач в Чехословакии. Прага, 1939. № 1/2. C. 5-19.

Теребинский В.И. По поводу болезни Гоголя // Русский врач в Чехословакии. Прага, 1939. № 4. С. 61-72.

Туроверов Н. Гоголь: [стихотворение] // Туроверов Н. Стихи. Книга четвертая. Париж, 1942.

[Перепечатано: Русская Мысль. Париж, 1952. 5 марта. № 429; Трудный Путь. Зарубежная Россия и Гоголь / Сост., вступ. статья и коммент. М.Д. Филина. М.: Русскій Міръ, 2002. С. 139-140.]

Чернылевский Н.Г. Полное собрание сочинений. / Под общ. ред. В.Я. Кирпотина, Б.П. Козьмина, П.И. Лебедева-Полянского и др. М.: Гослитиздат, 1939-1953.

Т. 1: Дневники. Автобиография. Воспоминания / Под ред. Б.П. Козьмина. М.: Гослитиздат, 1939. $860 \mathrm{c}$.

[О Гоголе: С. 30, 54, 68-72, 96, 135 и др.]

Чурилина М. Любимый автор // Комсомольская правда. М., 1939. 1 апреля. № 74.

[О Гоголе.]

Шевченко Т.Г. Полное собрание сочинений: В 10 т. Киев: Академия наук УССР, 1939 1958.

[Вышло 6 т.]

Т. 1. Киев, 1939.

Гоголю: [стихотворение]. С. 250.

Т. 5: Дневник.

[О Гоголе: С. 125-126.]

Шкловский В.Б. Заметки о Гоголе // Знамя. М., 1939. № 7-8. С. 305-310. 
Щербина В. Н.В. Гоголь (К 130-летию со дня рождения) // Красная звезда. М., 1939. 30 марта. № 72 .

Автор-составитель:

Владимир Алексеевич Воропаев, докт. филол. наук

профессор

филологический факультет

МГУ имени М.В. Ломоносова

\section{Author-composer:}

Vladimir A. Voropaev,

Doctor of Philology

Professor

Philological Faculty

Lomonosov Moscow State University

voropaevvl@bk.ru 